\title{
Survey and home range analyses of wintering shorebirds using the Lanark Reef Shorebird Complex, Franklin Co., Florida
}

Christine Marie Gunnels

West Virginia University

Follow this and additional works at: https://researchrepository.wvu.edu/etd

\section{Recommended Citation}

Gunnels, Christine Marie, "Survey and home range analyses of wintering shorebirds using the Lanark Reef Shorebird Complex, Franklin Co., Florida" (1999). Graduate Theses, Dissertations, and Problem Reports. 965.

https://researchrepository.wvu.edu/etd/965

This Thesis is protected by copyright and/or related rights. It has been brought to you by the The Research Repository @ WVU with permission from the rights-holder(s). You are free to use this Thesis in any way that is permitted by the copyright and related rights legislation that applies to your use. For other uses you must obtain permission from the rights-holder(s) directly, unless additional rights are indicated by a Creative Commons license in the record and/ or on the work itself. This Thesis has been accepted for inclusion in WVU Graduate Theses, Dissertations, and Problem Reports collection by an authorized administrator of The Research Repository @ WVU. For more information, please contact researchrepository@mail.wvu.edu. 


\title{
Survey and Home Range Analyses of Wintering Shorebirds Using the Lanark Reef Shorebird Complex, Franklin Co., Florida
}

\author{
Christine M. Gunnels \\ Thesis submitted to the faculty of West Virginia University in partial fulfillment of the \\ requirements for the degree of \\ Master of Science \\ In \\ Wildlife and Fisheries Resources \\ Robert Whitmore, Ph.D., Chair \\ John Edwards, Ph.D. \\ Linda Butler, Ph.D. \\ Department of Wildlife and Fisheries Resources
}

Morgantown, West Virginia

1999

Keywords: counts, home range, regression, shorebirds

Copyright (C) 1999, Christine M. Gunnels 


\section{ABSTRACT \\ Survey and Home Range Analyses of Wintering Shorebirds Using the Lanark Reef Shorebird Complex, Franklin Co., Florida}

\section{Christine M. Gunnels}

Radio telemetry was used to document spatial variation in use by wintering shorebirds at a series of sites believed to form the Lanark Reef Shorebird Complex in Franklin County. Fifty and 95\% convex polygon home range estimate for Willets (Catoptrophorus semipalmatus) averaged 0.52 $\mathrm{km}^{2}$ and $14.85 \mathrm{~km}^{2}$, respectively. Fifty and $95 \%$ convex polygon home range estimate for the Black-bellied Plover (Pluvialis squatarola) averaged $<0.01 \mathrm{~km}^{2}$ and $0.10 \mathrm{~km}^{2}$, respectively. Fifty and 95\% convex polygon for the Marbled Godwit (Limosa fedoa) and Long-billed Curlew (Numenius americanus) was $0.32 \mathrm{~km}^{2}$ and $6.72 \mathrm{~km}^{2}$, and $0.36 \mathrm{~km}^{2}$ and $24.41 \mathrm{~km}^{2}$, respectively. Black-bellied Plovers appeared to have the smallest distance between locations followed by Willets, Long-billed Curlews and Marbled Godwits.

Replicate shorebird surveys were conducted on the reef and count data were regressed against four environmental variables (wind speed, tide height, cloud cover, and temperature). Regression results $\left(R_{a d j}^{2}\right)$ accounted for $45 \%$ and $66 \%$ of the variance in total shorebird counts on the Reef for 1996 and 1997, respectively. Shorebird total counts were positively correlated with tide height for 1996 and $1997(P<0.01)$. 


\section{Acknowledgments}

I would like to thank the Florida Game and Fresh Water Fish Commission for enabling me to take these data I collected for the Commission and use them to pursue my Master of Science degree at West Virginia University. Additionally I would like to thank Dr. Whitmore for accepting me into to the Wildlife and Fisheries Resources Program and for his quick turn around with thesis edits. I would also like to thank my committee members Dr. John Edwards and Dr. Linda Butler for their comments, suggestions, and time to listen. I would like to also give an extra thanks to Dr. Edwards, a new professor at West Virginia University, who took extra time out of his schedule to design a course suited towards my academic and professional interests in ecology.

I would also like to give a special thanks to Dr. Dave Samuel who always had the time to listen and for providing good suggestions and financial aid all of which helped to further my learning and career goals.

Additionally, I would like to thank Dr. Michael Vaughan at Virginia Polytechnic and State University and Gary Sprandel with the Florida Game and Fresh Water Fish Commission, both of whom have always provided great advice for both technical and supportive problems encountered while completing this degree.

Perhaps the most important person I would like to thank is my husband Joey Gabbard. Joey has always had TONS of love, patience, and encouragement. And as if these qualities are not enough he is also one of the most intelligent people around --- helping me out of most any jam imaginable. Thanks babe, I love you. Additionally, I would like to thank my family who always provides unconditional love, support, and encouragement.

Lastly I would like to thank God for all the beautiful and amazing wildlife placed on this wonderful earth with which I have had the privilege to work with over the years. Respect for these creatures has been the driving force behind my desire to become a biologist. 


\section{Table of Contents}

Preliminary Pages

Acknowledgments ............................................ $i i i$

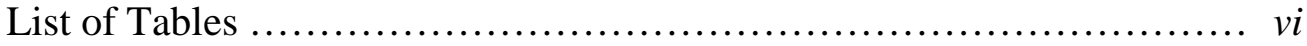

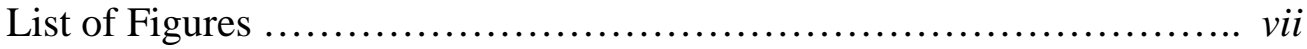

Chapter One: Wintering shorebird site use and movement in the Lanark Reef Shorebird Complex and Comparison of Three Home Range Analyses

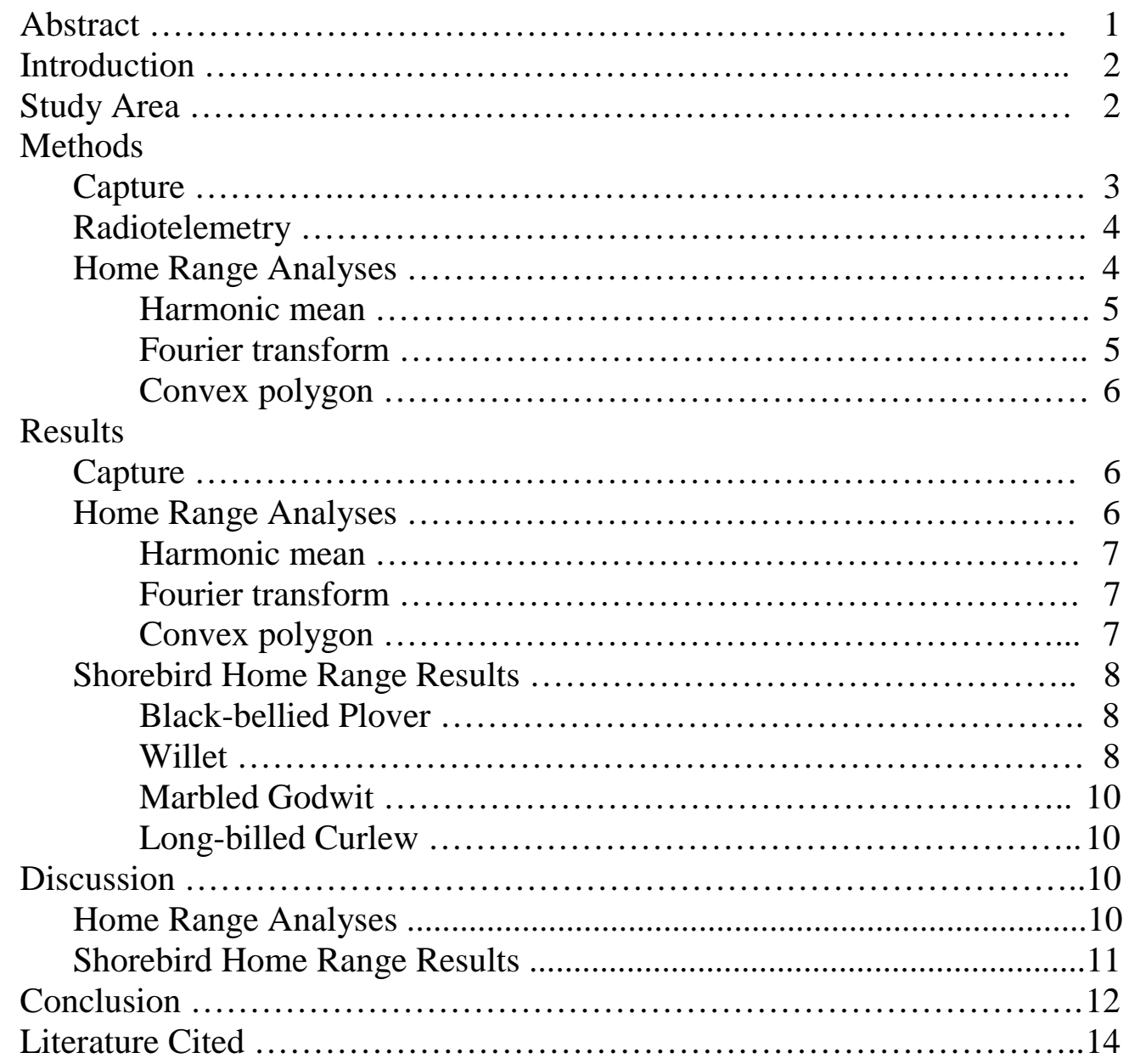

Chapter Two: Understanding variation in wintering shorebird count data

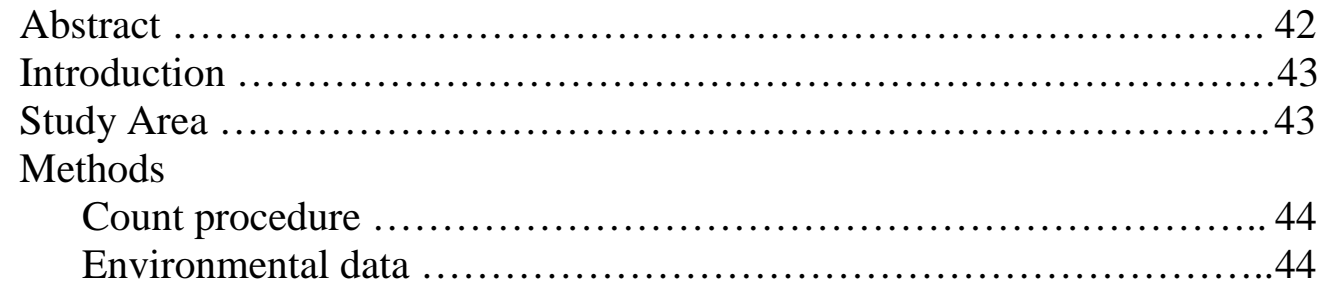




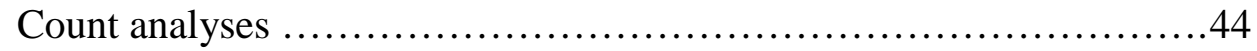

Results .......................................................... 45

Discussion ....................................................46

Literature Cited ................................................... 48

Appendix A: Shorebird species abbreviations ....................... 55 


\section{List of Tables}

\section{Chapter One}

Table 1.1

Home range estimates for wintering shorebirds from December - February 1995 - 1996 and 1996 - 1997 in the Lanark Reef Shorebird Complex, Franklin County, Florida.

Table 1.2 Comparison of standardized grid points to computer generated grid points for determining harmonic mean home range estimates for shorebirds in the Lanark Reef Shorebird Complex, Franklin County, Florida, December February 1995 - 1996 and 1996 - 1997.

Table 1.3 Maximum distance between telemetric locations for wintering shorebirds from December - February 1995-96 and 1996-97 in Lanark Reef shorebird complex, Franklin County, Florida.

\section{Chapter Two}

Table 2.1

Counts and environmental conditions during the three maximum and minimum counts of total shorebird species on Lanark Reef, Franklin, Co., Florida for 1996 and 1997.

Table 2.2 The percent of the total count, delineated by the low, medium, and high tidal ranges, for each species on Lanark Reef, Franklin County, Florida for 1996 and 1997.

Table 2.3 Correlation coefficients for total count of all species on Lanark Reef, Franklin, Co., Florida for 1996 and 1997 and the environmental variables. 


\section{List of Figures}

\section{Chapter One}

Figure 1.1

Figure 1.2

Figure 1.3

Figure 1.4

Figure 1.5

Figure 1.6

Figure 1.7

Figure 1.8

Figure 1.9

Figure 1.10

Lanark Reef Shorebird Complex, Franklin County, Florida, 1995-1996.

Inherent variation within each home range estimate using Willet 550's telemetry locations, collected in the Lanark Reef Shorebird Complex, Franklin County, Florida, December 1996 to February 1997.

Increase in $95 \%$ harmonic mean home range estimate with increasing number of Willet 550's radio telemetry locations, collected in the Lanark Reef Shorebird Complex, Franklin County, Florida, December 1995 to February 1996.

Increase in $95 \%$ Fourier transform home range estimate with increasing number of Willet 550's radio telemetry locations, collected in the Lanark Reef Shorebird Complex, Franklin County, Florida, December 1995 to February 1996.

Increase in $95 \%$ convex polygon home range estimate with increasing number of Willet 550's radio telemetry locations, collected in the Lanark Reef Shorebird Complex, Franklin County, Florida, December 1995 to February 1996.

The $50 \%$ and $95 \%$ convex polygon home ranges and core area for Black-bellied Plover 109, based on telemetric observations in Franklin County, Florida, 2 December 1995 to 20 February 1996.

The $50 \%$ and $95 \%$ convex polygon home ranges and core area for Black-bellied Plover 032, based on telemetric observations in Franklin County, Florida, 2 December 1995 to 20 February 1997.

The $50 \%$ and $95 \%$ convex polygon home ranges for Willet 154 , based on telemetric locations in Franklin County, Florida, 1 December 1995 to 10 January 1996.

The $50 \%$ and $95 \%$ convex polygon home ranges for Willet 125 , based on telemetric locations in Franklin County, Florida, 1 December 1995 to 10 January 1996.

The $50 \%$ and $95 \%$ convex polygon home ranges for Willet 210 , based on telemetric locations in Franklin County, Florida, 1 December 1996 to 28 February 1997.

Figure 1.11 The $50 \%$ and $95 \%$ convex polygon home ranges for Willet 350 , based on vii 
telemetric locations in Franklin County, Florida, 1 December 1996 to 28 February 1997.

Figure 1.12 The 50\% and 95\% convex polygon home ranges for Willet 469, based on telemetric locations in Franklin County, Florida, 1 December 1996 to 28 February 1997.

Figure 1.13 The 50\% and 95\% convex polygon home ranges for Willet 529, based on telemetric locations in Franklin County, Florida, 1 December 1996 to 28 February 1997.

Figure 1.14 The 50\% and 95\% convex polygon home ranges for Willet 550, based on telemetric locations in Franklin County, Florida, 1 December 1996 to 28 February 1997.

Figure 1.15 The 50\% and $95 \%$ convex polygon home ranges for Willet 572, based on telemetric locations in Franklin County, Florida, 1 December 1996 to 28 February 1997.

Figure 1.16 The $50 \%$ and $95 \%$ convex polygon home ranges for Willet 631 , based on telemetric locations in Franklin County, Florida, 1 December 1996 to 28 February 1997.

Figure 1.17 The $50 \%$ and $95 \%$ convex polygon home ranges for Willet 651 , based on telemetric locations in Franklin County, Florida, 1 December 1996 to 28 February 1997.

Figure 1.18 The 50\% and 95\% convex polygon home ranges for Marbled Godwit 311, based on telemetric locations in Franklin County, Florida, 1 December 1996 to 28 February 1997.

Figure 1.19 The 50\% and 95\% convex polygon home ranges for Long-billed Curlew 189, based on telemetric locations in Franklin County, Florida, 1 December 1996 to 28 February 1997.

\section{Chapter Two}

Figure 2.1

Lanark Reef Shorebird Complex, Franklin County, Florida 1995-97.

Figure 2.2 The location at low tide of quadrants on Lanark Reef, Franklin Co., Florida used for counting shorebirds.

Figure 2.3 Average number of individual species counted on Lanark Reef, Franklin Co., Florida, January -March 1996 and January - February 1997. 


\title{
Wintering Shorebird Site Use and Movement in the Lanark Reef Shorebird Complex and Comparison of Three Home Range Analyses
}

\author{
Christine Gunnels
}

\section{(ABSTRACT)}

Radio telemetry was used to document spatial variation in use by wintering shorebirds at a series of sites believed to form the Lanark Reef Shorebird Complex in Franklin County. Fifty and 95\% convex polygon home range estimate for Willets (Catoptrophorus semipalmatus) averaged 0.52 $\mathrm{km}^{2}$ and $14.85 \mathrm{~km}^{2}$, respectively. Fifty and $95 \%$ convex polygon home range estimate for the Black-bellied Plover (Pluvialis squatarola) averaged $<0.01 \mathrm{~km}^{2}$ and $0.10 \mathrm{~km}^{2}$, respectively. Fifty and 95\% convex polygon for the Marbled Godwit (Limosa fedoa) and Long-billed Curlew (Numenius americanus) was $0.32 \mathrm{~km}^{2}$ and $6.72 \mathrm{~km}^{2}$, and $0.36 \mathrm{~km}^{2}$ and $24.41 \mathrm{~km}^{2}$, respectively. Black-bellied Plovers appeared to have the smallest distance between locations followed by Willets, Long-billed Curlews and Marbled Godwits. 


\section{Chapter 1 - Wintering Shorebird Site Use and Movement in the Lanark Reef Shorebird Complex and Comparison of Three Home Range Analyses}

\section{INTRODUCTION}

Shorebird habitat is disappearing at an alarming rate (Myers 1983). The tendency of wintering shorebirds to congregate in large numbers at a limited number of sites makes them highly susceptible to disturbance and habitat degradation or loss. Forty-seven of 49 species of shorebirds that breed in North America live in Florida throughout the year (Robertson and Woolfenden 1992). There has been a decline of Florida's wintering shorebird habitat (Sprandel and Gore 1994). In addition, there is a paucity of information about site use and movements of wintering shorebirds in Florida or elsewhere in the southeastern United States. Consequently, wintering shorebirds have been identified through long-term planning projects, by the Florida Bureau of Nongame Wildlife, as a group of coastal wildlife species for which conservation should be a priority (Millsap et al. 1990, 1991).

Lanark Reef, a small island off the Florida panhandle, supported a combined average of $3.3 \%$ of the Atlantic Flyway population and $23.6 \%$ of the Florida winter population for the following species of shorebirds: Marbled Godwit (Limosa fedoa), American Oystercatcher (Haematopus palliatus), Snowy Plover (Charadrius alexandrinus), Piping Plover (C. melodus), and Willet (Catoptrophorus semipalmatus) (names follow American Ornithological Union 1998) (Sprandel et al. 1997). The Reef is an isolated, stable island near a highly dynamic intertidal area, an optimal area to study use by wintering shorebirds. Sprandel et al. (1997) concluded, from the 1994 statewide survey of wintering shorebirds in Florida, that Lanark Reef was the most biologically important high tide roost site in Florida. It supported an average of 1,872 birds composed of 15 different species, more than two times as many wintering shorebirds as the 13 other commonly used areas in Florida panhandle (Sprandel and Gore 1994).

Presumably, shorebird diversity associated with the reef may be attributable to it's unique intrinsic qualities. To investigate the relationship, I studied wintering shorebirds in the Lanark Reef shorebird complex from 11 November 1995 - 5 March 1996 and from 12 November 1996 27 February 1997. With the use of radio telemetry, I examined distance between feeding and roosting sites, areas used during inclement weather, and home range size. In this study I will present general shorebird habitat use data, and information on the ecological role the reef plays in the shorebird complex.

\section{STUDY AREA}

Lanark Reef shorebird complex is comprised of a series of sites east of the Carrabelle River to Shell Point including East of Bay North, Phipps Preserve, Lanark Reef and Dog Island (Fig.1.1). The percentage of suitable habitat found in the complex fluctuates with tide height. At low tide, there is an expanse of exposed sand and mud flats. High tide covers a majority of these exposed areas. Precipitation ranges from $132-152 \mathrm{~cm} / \mathrm{yr}$ (Wolfe et al. 1988).

Lanark Reef is a small island commonly used by roosting shorebirds (Fig. 1.1). The 
west-end is located west at $84^{0} 34^{\prime} 979^{\prime \prime}$ and north at $29^{\circ} 52^{\prime} 416^{\prime \prime}$, approximately $1 \mathrm{~km}$ off the coast of the Florida Panhandle in Franklin County. Human activity on the islands minimal during this study period. Once on the island, human presence was only obvious from litter which washed in with the tides, houses which could be seen on the mainland, and an occasional boat seen from shore.

Dog Island is a barrier island located approximately $5 \mathrm{~km}$ south of Lanark Reef. The position of this island subdues the effect of storm surges on Lanark Reef; therefore, erosion is minimal (Jim Ladner, FL Geological Survey, pers. comm.). Variable amounts of land were exposed during different tide heights. At low and high tides, 0.3 and $0.02 \mathrm{~km}^{2}$ of the reef were exposed, respectively.

The habitat on Lanark Reef consisted of mostly sand flats (comprised of sand and shell fragments) with mud flats occurring at low tide on the eastern and western ends. The middle of the island was densely vegetated with seagrass (Thalassia spp) and small succulent bushes (Salicornia spp) (Wolfe et al. 1988). This vegetation became sparse toward the east and westerly areas. The soil types found on the reef were Mandarin-Resota-Leon and Duckston sand (Sasser et al. 1994).

\section{METHODS Capture}

Beginning 11 November 1996 shorebirds were trapped at high tide on Lanark Reef when there were large congregations of target species (e.g., Willets, Marbled Godwits, American Oystercatchers, and Black-bellied Plovers). The first trapping attempts used a variety of methods during the day at high tide: mist nets, a Fundy pull trap (Hicklin et al. 1989), and a net gun (Coda Enterprises Inc., 1038 E. Norwood, Mesa, AZ, 85203). Because the birds could see the trapping devices, many became frightened and skittish; therefore, trapping was continued with black colored mist nets at night. Trapping birds at night provided the most success but was still difficult due to the continued visibility of the nets. Unfortunately, the use of cannon nets in this study area was not possible. The tendency of these birds to congregate in large masses while standing in a few inches of water made the chance of death due to drowning, once covered with the cannon net, too high.

Beginning 12 November 1996, I tiered two nets using a tan color on the bottom tier, topped with black net on the top tier and again attempted to trap the birds at night at high tide. This coloration made the nets more cryptic against the sand and the night sky. Initially, after the nets were in place, 3-4 observers walked slowly toward the roosting birds. When approaching within approximately $20 \mathrm{~m}$, observers made loud noises and shined flashlights to flush the birds toward the mist nets. After flushing, the birds often veered over the nets. Flushed birds appeared to use a rather circular flight pattern, as opposed to a more linear flight pattern when not flushed. Later, capture was attempted without flushing by catching those birds flying into and away from the common roost site. The non-flushing method appeared to work with more success.

Upon capture, non-target individuals were removed from the nets, identified, weighed, 
and released; target species weighing $>185 \mathrm{~g}$ were removed and placed in a holding box. The target species, Willets, Black-bellied Plovers (Pluvialis squatarola), Marbled Godwits, and a Long-billed Curlew (Numenius americanus), were fitted with a United States Fish and Wildlife Service (USFWS) and unique combination of color-coded UV-resistant leg bands. In 1995, a 6.0-g radio transmitter (American Wildlife Enterprises, Tallahassee, FL 32312) were either glued to the shorebirds' lower back (Warnock and Warnock 1993) using an epoxy developed for use on seabirds (epoxy adhesive \#332, Titan Corporation, 5629 208th St. S.W., Lynwood, WA 98036) or birds were fitted with a standard backpack harness (Rappole and Tipton 1991). The harness was made of $36 \mathrm{~kg}(80 \mathrm{lb}$.) test dacron cord. Due to the low survival of birds and technical difficulties with American Wildlife Enterprise's transmitter, a smaller $(3.5 \mathrm{~g})$, cryptically colored (i.e., gray or black depending on species coloration), and hermetically sealed transmitter (Holohill Inc.,112 John Cavanagh Rd., Carp, Ontario, Canada K0A 1L0) was used during the 1996 trapping season. Transmitters from American Wildlife Enterprises had an approximate range of $2 \mathrm{~km}$ and a life span of 3 months. Trapping was discontinued after 15 December 1995 (the first field season), because of transmitter failures and our resulting inability to readily locate birds. After affixing all purchased transmitters in the second field season, 11 December 1996 was the last trap night.

\section{Radiotelemetry}

Location of transmittered birds began after a 3-day acclimation period (White and Garrott 1990). Radio telemetry was conducted using a Telonics receiver (Telonics, Inc., Mesa, AZ, 85204-6699) and a 3-element yagi antennae. The study area was searched by boat or car and transmitter signals were used to facilitate visual observations. When I could not locate birds from the ground, standard aerial location procedures were used (Mech 1983). Coordinates for each ground and aerial location were recorded using a Trimble GPS (Trimble Navigation, Ltd., Sunnyvale, CA, 94088-3642) or Loran unit, respectively. Environmental variables (wind speed and direction, temperature, and tide height) were recorded concomitantly with radio telemetry data. Tidal ranges were delineated on home range maps. The range of adjusted tides (discussed below) was determined for 1996 and 1997 and then separated evenly: low $\leq 0.82 \mathrm{~cm}$, medium > 0.82 and $\leq 1.35 \mathrm{~cm}$, and high $>1.35 \mathrm{~cm}$.

To minimize correlation, radio-locations were scheduled so that a bird could cover it's home range between locations (White and Garrott 1990). Locations were >30 minutes apart, this gave the bird ample time to traverse it's home range but also allowed me to qualitatively determine the effect of tidal movements on habitat preference.

\section{Home Range Analyses}

GPS files were downloaded using GPS Pathfinder Basic Plus software (Trimble Navigation, Ltd., Sunnyvale, CA, 94088-3642) and differentially corrected using Tallahassee, FL or Auburn, AL base station files. Atlas GIS (Strategic Mapping, Inc., Santa Clara, CA 95051) was used to convert latitude and longitude to UTM coordinates. Autocorrelation tests (correlated if $\gamma>0.3$ at $P<0.05$ ) (Swihart and Slade 1986), and home range analyses were conducted using the program Home Range (Ackerman et al. 1990). For each of these analyses, the capture location was included as a point. 
To insure comparability, home range estimates derived from several different methods were calculated, therefore increasing the chance my results can be compared with other studies (Anderson 1982). Two nonparametric home range estimates, the harmonic mean (Dixon and Chapman 1980) and Fourier transform (Anderson 1982); and the minimum convex polygon (Mohr 1947) were used to calculate the home range within a $95 \%$ and $50 \%$ isopleth. I examined the effect sample size had on each analysis by re-calculating home range with each additional location, plotting home range size as a function of increasing locations for each analysis, and determining which analysis reached asymptote first. In addition, the variation within each estimate was determined using SigmaStat ${ }^{\circledR}$ to calculate Kruskal -Wallis one way analysis of variance on ranks on repeated $(N=10)$ random home range calculations within a predetermined sample size (i.e., $N=10,20,30,40$ ) (Jandel Scientific 1994). Then using SigmaStat ${ }^{\circledR}$, I calculated Student - Newman - Keuls pairwise multiple comparison procedure for nonparametric data to isolate which of the three home range analysis results significantly differ $(P<$ 0.05) (Jandel Scientific 1994). The pros and cons for each analytical method were determined in three ways: from a literature review, by plotting the effect of additional locations, and by examining the variation within each estimate to determine which best fit these data.

Harmonic mean.-The harmonic mean produces a home range estimate based on the volume under a fitted three-dimensional utilization distribution (Ackerman et al. 1990) while allowing for multi-modal centers of activity and identifying outliers (Dixon and Chapman 1980). This estimator was the least precise when estimating home ranges with geographic barriers or when using a small sample sizes (Boulanger and White 1990). The harmonic mean was also sensitive to scale, and home range estimates can only be compared if the grid size and plot scale are the same for and within each study (Dixon and Chapman 1980, White and Garrott 1990, Ackerman et al. 1990). In setting the parameters, one runs the risk of having a location fall on or close to a grid node (point at which the $\mathrm{x}$ and $\mathrm{y}$ axis cross on the gird), creating biased estimates (Worton 1987, Boulanger and White 1990). I used the following parameters for each home range analysis: grid points $\mathrm{x}=35, \mathrm{y}=16$; plot scale $1550 \mathrm{~m}=2.54 \mathrm{~cm}$. The grid points define the size of the grid used to determine the harmonic mean, and the plot scale provides the scale used for the plotted output (Ackerman et al. 1990).

The core area was defined by comparing the observed space-use patterns with that expected from a uniform distribution (Samuel et al. 1985). The size and location of the core area depends upon the method used to determine core size; the home range package (Ackerman et al. 1990) used the harmonic mean estimate. Therefore, one should be reminded of the harmonic mean's inherent biases. The 50\% convex polygon has been used by others to represent the core area for an animal (Michener 1979, Bowen 1982); however, the 50\% convex polygon does not allow for bimodal habitat use. For example, the convex polygon does not represent two heavily used areas with separate isopleths, instead both areas are encompassed by one isopleth.

Fourier transform.-The Fourier transform bases a home range estimate on an animal's utilization distribution (White and Garrott 1990, Ackerman et al. 1990). This approach requires a large sample size (i.e., $N>100$ ) because of the difficulty in defining the edges of home ranges from small samples (Anderson 1982, Worton 1987, Ackerman et al. 1990). However, using a $50 \%$ home range estimate may overcome this problem (Anderson 1982). For home ranges 
which include geographic barriers, Boulanger and White (1990) found that the Fourier transform had a positive bias for small $(N=50)$ and large $(N=150)$ sample sizes; although, the precision of the estimate significantly improved $(P<0.0001)$ with increased observations. Boulanger and White (1990) discouraged use of the Fourier estimate.

Convex polygon.-The convex polygon is one of the most widely used home range estimators (White and Garrott 1990). It was constructed by connecting a predetermined percentage of outer locations producing a convex polygon (White and Garrott 1990). Because of the flexibility it allows in the shape of the home range, the convex polygon estimator has a lower variance for home ranges where geographic barriers exist (Boulanger and White 1990, White and Garrott 1990). Disadvantages of the convex polygon method include an indefinitely increasing home range estimate with increasing sample size (Jennrich and Turner 1969) and the strong bias created by outliers (Ackerman et al. 1990). Additionally, the convex polygon estimator is only based on two dimensions; therefore, weight is not given to areas with multiple locations.

\section{RESULTS \\ Capture}

From 11 November - 15 December 1995 I trapped on 8 nights and 5 days, capturing 16 target and 84 non-target individuals using black mist nets. Six of the 84 non-target species and none of the target species were captured during the day. Transmitters were attached to all 16 target individuals ( 8 backpack harnessed and 8 glued). By the seventh week in the firt field season all but one transmittered birds had been predated or were censored. The only remaining bird carried a transmittered glued to it's back.

From 12 November - 11 December 1996 I trapped on 16 nights, capturing 31 target and 168 non-target birds using a combination of tan and black mist nets. All transmitters were glued on target individuals. There were no known mortalities in the second field season.

Target birds were never caught using mist-nets, net-gun, or the Fundy pull-trap during the day, apparently because the trapping devices were too conspicuous. For both years, qualitatively the best trapping conditions occurred during high tide and dark skies with low wind speeds. High tide limited the availability of exposed land for birds to roost, therefore nets could be placed in close proximity $(\leq 50 \mathrm{~m})$ to the few available roost sites and birds could be caught while flying in and away from the roost site. Dark skies and low wind speeds decreased the visibility of the mist nets.

\section{Home Range Analyses}

I chose to include birds with at least 10 telemetric locations. The effect of sample size was examined for Willets only, because they were the only species with $>2$ birds in this study. Although the exact sample size at which asymptote is reached varies, many Willets' home ranges tend to level off around the tenth location when using the convex polygon estimate as was seen with Willet 550 (Fig 1.5). This may appear to be a rather small sample for a home range estimate, but many locations were visual (i.e., exact location known) and therefore distance between locations could also be examined which provides useful area-use information. Of the 47 transmittered birds only 14 birds: 10 Willets, 2 Black-bellied Plovers, a Marbled Godwit, and 
a Long-billed Curlew had a sample size sufficient to include in these analyses. Using the gamma index $(\gamma>0.3)$ for serial correlation (Swihart and Slade 1986), 2 of the 14 transmittered birds locations were not independent (Willet 469: $\gamma=0.83, N=22$; Willet 631: $\gamma=0.47, N=53$ ). Results from all analyses and the actual sample size are listed for each bird in Table 1.1.

Providing home range estimates from a variety of analyses is beneficial for future comparisons (Anderson 1982). However, it is important to note the variation in median value for each analysis was greater than would be expected by chance $(P<0.01)$. Therefore, a more detailed examination was required to determine the best analysis for these data and is included below.

Harmonic mean.-The harmonic mean estimate was grid-based. In order to make comparisons grid parameters must be standardized among animals (Dixon and Chapman 1980, Ackerman et. al 1990, and White and Garrott 1990); moreover, manipulated grid parameters due to standardization tend to bias results (Worton 1987, Boulanger and White 1990). My data produced similar results; for example, Willet 350's 95\% harmonic mean estimate was 2 times greater with the computer generated parameters than with the standardized grid points (Table 1.2). Standardized grid parameters were necessary for comparisons among birds; however standardization increased the chance of a location falling on a grid node and therefore resulted in biased home range estimates.

Harmonic mean estimates are also inaccurate with geographic barriers (Boulanger and White 1990). In these shorebird data, the harmonic mean had the most variation within replicated estimates (Fig. 1.2) and produced significantly larger $(P<0.01)$ estimates. In addition, the $95 \%$ estimate increased with increasing sample size for Willet 550 (Fig. 1.3); the rest of the birds had similar results. In spite of the biases inherent when applying the harmonic mean, I did map the core area for each bird using this estimate because it represented bimodal habitat use. Two core areas within a home range appear to be prominent with wintering shorebirds at the Lanark Reef complex.

Fourier transform.-In previous studies the Fourier estimate produced positively biased data for small and large sample sizes for home ranges with geographic barriers (Boulanger and White 1990). It has been suggested that sample sizes should be $N \geq 100$ (Anderson 1982, Worton 1987, and Ackerman et al. 1990). Our largest sample size was 58 locations. In this study the Fourier transform had the lowest inherent variance (Fig. 1.2). However, with increasing sample size for Willet 550 the Fourier estimate fluctuated and did not approach an asymptote as quickly as the convex polygon (Fig. 1.4). Similar results were seen with other transmittered birds.

Convex polygon.-The convex polygon had a lower variance with geographic barriers when compared to other estimates (Boulanger and White 1990, White and Garrott 1990). Geographic barriers must be considered in our case because much of our birds' home ranges were irregularly shaped due to the influences of the Gulf of Mexico and the orientation of the Reef to the mainland. The $95 \%$ convex polygon estimate had lower inherent variation than the harmonic mean (Fig. 1.2) and was the least affected by increasing sample size when compared to 
the harmonic mean and the Fourier transform (Fig. 1.5). Furthermore, it is the most commonly used home range estimator; therefore comparisons with past and future research are more possible. I believe the convex polygon was the best home range estimate of those offered within the Home Range Program (Ackerman et al. 1990). Subsequently, data for all analyses were only included within Table 1.1 and the following more detailed results were derived from convex polygon data, unless otherwise stated.

\section{Shorebird Home Range Results}

Black-bellied Plover.-Black-bellied plover 109 had 50\% and 95\% convex polygon estimates of $<0.01 \mathrm{~km}^{2}$ and $0.04 \mathrm{~km}^{2}$, respectively (Table 1.1). All locations were made on Lanark Reef where this bird was seen both feeding and roosting. The 50\% convex polygon included locations exclusively on the western tip on Lanark (Fig. 1.6). The maximum distance between locations was $0.5 \mathrm{~km}$, which was the shortest for all the transmittered birds (Table 1.3).

Black-bellied plover 032 had $50 \%$ and $95 \%$ convex polygon estimates of $<0.01 \mathrm{~km}^{2}$ and $0.15 \mathrm{~km}^{2}$, respectively (Table 1.1 ). All locations for both polygons included locations toward the western end of Lanark Reef. The $95 \%$ polygon had only $0.5 \mathrm{~km}$ between the most distant locations. The core area included one roost location on the eastern end. The maximum distance between locations was $4.0 \mathrm{~km}$ including a location at low tide on the sand spit west of Lanark Reef (Fig. 1.7). The Black-bellied Plovers were the only birds to use the reef so exclusively. Both contained less than $0.6 \mathrm{~km}$ between the farthest points within the $95 \%$ isopleth (Table 1.3).

Willet.- Willet $125 \mathrm{had} 50 \%$ and $95 \%$ convex polygon estimates of $0.34 \mathrm{~km}^{2}$ and 2.91 $\mathrm{km}^{2}$, respectively (Table 1.1 ). The $50 \%$ convex polygon included locations on the west end of Lanark and the trailer park to the north. The $95 \%$ convex also included a feeding location on the sand spit to the west (Fig. 1.8). The core area surrounded the roost site at the trailer park. The maximum distance between locations was $4.0 \mathrm{~km}$ (Table 1.3).

Willet 154 had $50 \%$ and $95 \%$ convex polygon home range estimates of $0.03 \mathrm{~km}^{2}$ and $4.21 \mathrm{~km}^{2}$, respectively (Table 1.1 ). The most distant locations within the $50 \%$ convex polygon isopleth were $0.08 \mathrm{~km}$ apart. All the locations were along the mainland at a trailer park north of the reef; a common roost site. The $95 \%$ convex polygon included feeding sites at the sand spit to the west and, as the tide came in, on the mudflats to the north (Fig. 1.9). The core area surrounded the trailer park common roost site and the mudflats along the mainland to the west. The maximum distance between locations was $5.2 \mathrm{~km}$ (Table 1.3).

Willet 210 had $50 \%$ and $95 \%$ convex polygon estimates of $0.82 \mathrm{~km}^{2}$ and $4.97 \mathrm{~km}^{2}$, respectively (Table 1.1). The 50\% convex polygon isopleth included mostly roosting locations on the west-end of Lanark and the trailer park. The $95 \%$ convex polygon contained feeding sites at the sand spit to the west and, as the tide came in, on the mudflats to the north (Fig. 1.10). Although this bird tended to use feeding and roosting sites at or near the reef, I did find it $9.0 \mathrm{~km}$ away on Dog Island, at high tide, on two consecutive days.

Willet 350 had $50 \%$ and $95 \%$ convex polygon estimates of $0.18 \mathrm{~km}^{2}$ and $5.29 \mathrm{~km}^{2}$, respectively (Table 1.1). The most distant locations within the $50 \%$ convex polygon isopleth 
were $0.55 \mathrm{~km}$ apart, all included on Lanark Reef. The $95 \%$ polygon locations also included the sand spit to the east (Fig. 1.11). The core area included locations along the west and the east ends of Lanark Reef where this bird tended to roost during high tides (Fig. 1.11). The greatest distance between all the locations was $16.6 \mathrm{~km}$ (Table 1.3). It should be noted, there were few samples for this bird and only one during low tide. Most locations were of this bird at roost.

Willet 469 had $50 \%$ and $95 \%$ convex polygon estimates of $2.59 \mathrm{~km}^{2}$ and $65.88 \mathrm{~km}^{2}$, respectively (Table 1.1). The most distant locations within the 50\% convex polygon isopleth were $1.3 \mathrm{~km}$ apart exclusively located at Shell Point. Locations at the mudflats east of Bay North and Shell Point were included within the 95\% convex polygon (Fig. 1.12). The core area was represented by 2 non-adjacent areas $25.7 \mathrm{~km}$ apart. Core area A surrounds the mudflats and the unattached pier at Williams Beach. While at area A, Willet 469 used the pier during high tide to roost and fed at the mudflats. After 17 January 1997 Willet 469 moved to Shell Point where it appeared to remain through all the tidal ranges. Core area B included locations around Shell Point. The distance between Lanark Reef and Shell point was $49.9 \mathrm{~km}$, the two most distant points (Table 1.3).

Willet 529 had $50 \%$ and $95 \%$ convex polygon estimates of $0.02 \mathrm{~km}^{2}$ and $6.32 \mathrm{~km}^{2}$, respectively (Table 1.1). The most distant locations within the $50 \%$ convex polygon isopleth were $7.9 \mathrm{~km}$ apart on Lanark Reef. Locations at the mudflats east of Bay North, the mudflats east of the Village Fina, and Lanark Reef were included within the 95\% convex polygon (Fig. 1.13). The core area surrounded the reef and included locations from all the tidal ranges. The two most distant locations, were between the mudflats east of the Village Fina and the mudflats east of Bay North, a distance of $18.9 \mathrm{~km}$ (Table 1.3).

Willet 550 had $50 \%$ and $95 \%$ convex polygon estimates of $1.10 \mathrm{~km}^{2}$ and $11.08 \mathrm{~km}^{2}$, respectively (Table 1.1). The most distant locations within the 50\% convex polygon isopleth were $2.3 \mathrm{~km}$ apart. These included a feeding site at east of Bay North, and roost sites at the piers at Bay North and William's Beach. Additional locations at Lanark Reef and St. Teresa were also included within the $95 \%$ convex polygon (Fig. 1.14). The core area surrounded sites similar to the $95 \%$ convex polygon. The maximum distance between all locations was $17.2 \mathrm{~km}$ between Lanark Reef and east of Bay North (Table 1.3). Similar to Willet 469, after 23 January 1997, Willet 550 was not located on the reef and instead was found roosting and feeding at the piers and mudflats to the east.

Willet 572 had $50 \%$ and $95 \%$ convex polygon estimates of $0.14 \mathrm{~km}^{2}$ and $10.89 \mathrm{~km}^{2}$, respectively (Table 1.1). The most distant locations within the $50 \%$ convex polygon isopleth covered were $2.8 \mathrm{~km}$ apart. The $50 \%$ polygon included feeding locations at the mudflats east of Bay North and roosting locations at the pier at William's Beach. Feeding and roosting locations from Lanark Reef were also included in the 95\% convex polygon (Fig. 1.15). Willet 350 used two non-adjacent core areas. Core area A included tightly clustered locations at a roost site on the reef. Core area B included mostly feeding sites at the mudflats approximately $16.9 \mathrm{~m}$ from core A. There was $3.5 \mathrm{~km}$ between the middle of the two core areas. This bird's transmitter was found shortly after 17 January 1997 and therefore a shift in area used could not be determined. 
Willet 631 had $50 \%$ and $95 \%$ convex polygon estimates of $1.21 \mathrm{~km}^{2}$ and $34.59 \mathrm{~km}^{2}$, respectively (Table 1.1). The 50\% convex polygon included locations on Lanark Reef and the trailer park to the northwest. Many times this bird was found roosting on the pier at the first trailer park. Locations spanning west, past the Carrabelle River, and east to the mudflats east of Bay North were included within the 95\% convex polygon (Fig. 1.16). Willet 631 used two nonadjacent core areas. Core area $\mathrm{A}$ included feeding locations at the sand spit to the west and the grassy areas past the eastern tip of the reef. Known roost observations included Lanark Reef and two trailer parks to the northwest. Core area B included roosting sites at the piers east of Lanark and feeding sites at the mudflats east of Bay North. The east and west area of this study area (Fig. 1.1) were used intermittently over the study period. The distance between the two most distant locations was $16.9 \mathrm{~km}$ (Table 1.3).

Willet 651 had $50 \%$ and $95 \%$ convex polygon estimates of $0.08 \mathrm{~km}^{2}$ and $2.36 \mathrm{~km}^{2}$, respectively. The most distant locations within the $50 \%$ convex polygon isopleth were $0.5 \mathrm{~km}$ apart on the west-end of Lanark Reef, used to roost at high tide. The $95 \%$ convex polygon included low tide locations on the sand spit and mudflats to the northwest and the eastern end of the reef (Fig. 1.17). High tide sites included the east and west ends of the reef and the trailer park to the north. The core area included generally the same areas as the $95 \%$ convex polygon. This Willet used a relatively small area; consequently, there was only a distance of $5.2 \mathrm{~km}$ between the two most distant locations (Table 1.3).

Marbled Godwit.-Marbled godwit 310 had 50\% and 95\% convex polygon estimates of $0.32 \mathrm{~km}^{2}$ and $6.72 \mathrm{~km}^{2}$, respectively (Table 1.1). The most distant locations within the $50 \%$ convex polygon isopleth were $1.0 \mathrm{~km}$ apart on Lanark Reef, used for both roosting and feeding. The $95 \%$ convex polygon included additional feeding sites on the sand spit. In addition, I located this bird on the mudflats east and west of the mouth of the Carrabelle River (Fig. 1.18). High tide locations were clustered on the reef. Marbled Godwit 310 used two non-adjacent core areas. Core area A included the low tide locations centered around the sand spit to the west. Core area B surrounded the reef and was used for roosting and feeding. The distance between the two most distant locations was $23.8 \mathrm{~km}$ between the Carrabelle River and the mudflats east of Bay North (Table 1.3). After 17 January 1997 this Godwit was not found feeding at the mudflat east of Bay North but was found feeding at the areas closer to the reef. Interestingly, this was the opposite trend seen with many Willets that tended to use the mudflats east of Bay North more intensely around the third week of January 1997.

Long-billed Curlew.-Long-billed Curlew 189 had 50\% and 95\% convex polygon estimates of $0.36 \mathrm{~km}^{2}$ and $24.41 \mathrm{~km}^{2}$, respectively (Table 1.1). The most distant locations within the $50 \%$ convex polygon isopleth covered $1.7 \mathrm{~km}$ on Lanark Reef used mostly for roosting. The 95\% convex polygon included feeding locations almost exclusively at the mudflats east of Bay North and roost sites on the reef, the pier at the trailer park, the sand spit east of Bay North, and the pier at Williams Beach (Fig. 1.19). The Long-billed Curlew 189 used two non-adjacent core areas. Core area A included mostly roost locations at high tide clustered on the reef. Core area B surrounded at the mudflat east of Bay North and the pier at Williams Beach. The curlew was seen roosting and feeding at the mudflat and roosting on the pier. The distance between the two most distant locations was $18.1 \mathrm{~km}$ between the reef and the mudflats east of Bay North (Table 
1.3).

\section{DISCUSSION \\ Home Range Analyses}

Based on the results it appears the convex polygon best represents shorebird data. Although previous studies have reported an increase in home range size with each additional location (Jennrich and Turner 1969), this was not evident with these data. Shorebirds tend to use two (feeding and roosting) areas within their home range intensely. Few locations are found outside of these feeding and roosting areas, and therefore with each additional location the size of the polygon does not increase as is often seen with other animals.

\section{Shorebird Home Range Results}

It is imperative to carefully examine a terrestrial vertebrate's home range when it encompasses both land and water. Due to the nature of the convex polygon estimate, unused areas on the mainland and the Gulf of Mexico have been included in the maps. The majority of the Gulf included in each home range estimate simply represents an area each bird had to cross between roosting and feeding sites. Therefore, the greater the distance between low and high tide sites the more energy expended. Energy conservation is essential for these migratory species.

Based on the $95 \%$ convex polygon estimate Willets, the Marbled Godwit, and the Longbilled Curlew covered more area than the Black-bellied Plover 109 or 032 (Figs. 1.6-1.19). The Black-bellied Plovers were different from the other species in that Lanark Reef seemed to provide both feeding and roosting habitat. The Willet, Marbled Godwit, and Long-billed Curlew appeared to use the reef primarily for roosting and required additional feeding sites as well.

When comparing the difference in the amount of area used by the Willets, 3 groups become apparent. The group of Willets (identification numbers 125, 154, 210, and 651) with the most concentrated use of their home range had $<4 \mathrm{~km}$ between the two farthest points on the 95\% isopleth (Figs. 1.8-1.10 and 1.17). Site use appeared to be regulated by tide height. Generally, these birds roosted during mid-high tides on the reef, the trailer parks and the pier to the northwest, and fed during low-mid tides on the sand spit and the mudflats to the north on the mainland.

The second group of Willets (identification numbers 529, 572, and 631) covered $>4$ times the area of the aforementioned group's 95\% convex polygon home range estimate (Figs $1.13,1.15,1.16)$. These birds intermittently used sites within the entire shorebird complex. However, site use appeared to be regulated by tidal fluctuations. The majority of the birds had two core areas present, each core area encompassed a feeding and roosting site depending on the tide height. Generally, most of these birds fed during the lower tides at the mudflats east of Bay North, the sand spit, the mudflats to the north of the sand spit, and areas northeast of St. Teresa. Occasionally birds were also seen feeding on the reef. Common roost sites also included Lanark, the three piers along the mainland, and the trailer parks to the north.

The third group also covered a large distance; although it appears they may have reduced 
the area traversed as the study progressed (Figs. 1.12 and 1.14). Willet 469 was unique with the largest convex polygon home range $\left(65.88 \mathrm{~km}^{2}\right)$ with approximately $35 \mathrm{~km}$ between core areas. However, 469 did not appear to use the 2 core areas in conjunction with one another (Fig 1.12). Willet 469 was found on Lanark Reef and East of Bay North 11 December - 17 January 1997 after which 469 was found exclusively at Shell Point. Similarly, Willet 550's 95\% home range extends from East of Bay North, west to the reef (Fig. 1.14). However, upon further inspection this bird mainly used the reef as a roosting site at medium-high tides from 11 December -23 January 1997 and for the rest of the study period was found roosting during medium-high tides at the piers within $4 \mathrm{~km}$ of the mudflats at East of Bay North. There was one exception, on 13 February 1997 Willet 550 was found roosting on the reef during very inclement weather, i.e. high winds, heavy rain, and high tides. Conversely, Marbled Godwit 310 was not located on the eastern half of the study area after 17 January 1997.

The Long-billed Curlew used the shorebird complex habitat in a manner similar to that seen with the second group of Willets. It was located at both feeding and roosting sites throughout the entire shorebird complex. There was approximately $16 \mathrm{~km}$ between the two core areas. This bird used mudflats east of Bay North exclusively at low tide for feeding and roosted mainly on the reef at high tide. The Long-billed Curlew was rarely seen at any other locations.

Reducing the distance crossed between feeding and roost sites is physiologically economical. After migration, shorebirds need to restore expended energy reserves and build fat reserves for thermoregulation during the colder months and for spring migration. Unfortunately, during the winter, available prey decreases because at this time invertebrates do not reproduce and were found deeper in the substrate (Smith 1975, Evans 1988). Therefore, the less energy expended traveling between feeding and roosting sites the better. Perhaps, by reducing the area traversed between sites these birds were able to build fat reserves more efficiently.

\section{CONCLUSION}

As the years move on, human encroachment on critical shorebird habitat becomes an increasing concern. Therefore, understanding winter shorebird habitat use and determining a more accurate method for monitoring these species becomes increasingly important. It should be noted, the data set used in this study was small and may not represent variability in the range of shorebird behavior and additional research would be beneficial. However, from the data acquired, these birds tend to use small concentrated areas within their home range. Some primary roosting areas used by the shorebirds in 1995-1997 in the shorebird complex were the reef, the trailer park, pier 1, and pier 2, while feeding areas were Lanark Reef, the sand spit, East of Bay North, and St. Teresa. Due to the shorebirds' concentrated use of particular areas, it may not be necessary to manage an entire expanse of shoreline. Critical roosting and feeding areas such as Lanark Reef and east of Bay North need to be protected. However, the appropriate distance between feeding and roosting sites is still unknown. Kelly and Cogswell (1979) found that Willets primarily used 2 high tide roosts with feeding areas within $1000 \mathrm{~m}$. Eleven years earlier Luther (1968) reported $6100 \mathrm{~m}$ between roost and feeding sites. I have recorded distances many times greater than these sites and wonder if this increase in distance may be due to human exploitation and environmentally induced destruction of shorebird habitats. However, I noted a habitat use reduction trend with some of our birds. Willets 469 and 550 began the study period 
traversing a large expanse of land, but as the study progressed they used roosting and feeding sites with a more concentrated area. Perhaps the smaller home ranges may be preferred but not always attainable. To alleviate this problem I suggest maintaining existing piers or pier-like structures as roost sites near common or potential feeding areas. I noted $>100$ large shorebirds using three different piers for roosting within the study site. Although somewhat exposed, these structures provide undisturbed, dry roosting sites.

It is imperative to identify, study, and monitor the key feeding and roosting sites used by wintering shorebirds due to their annual concentrated use and site fidelity. Willets have been reported habitually using the same roosting and feeding areas each year (Kelly and Cogswell 1979). In 1996, I observed a Willet color-banded in January 1994 using a common roost site approximately $1500 \mathrm{~m}$ north of the reef along a $500 \mathrm{~m}$ shoreline where a majority of 154's locations were recorded (Fig 1.9). This bird was again seen in 1997 using the reef as a roost site. Upwards of $65 \%$ and $70 \%$ return rate have been reported for Willets and Marbled Godwits, respectively after migration (Kelly and Cogswell 1979).

In addition to revealing habitat use and it's variation due to tidal height, this study has also helped to provide insight on the importance of Lanark Reef for these birds. It was relatively stable, protected by Dog Island from storm surges, and experienced limited human disturbance. It was a primary roost and common feeding site. In fact, the Black-bellied Plovers appeared to use the reef exclusively to feed and roost. It was also apparent that during times of inclement weather the reef may provide protection. Similarly, Willets used alternate roost sites under times of high tide and disturbance (Kelly 1976). Due to the aforementioned reasons (i.e., stability, high shorebird use, minimal disturbance, and environmental protection), I feel Lanark Reef is an optimal area for preservation and for the continued monitoring of these migratory species. 


\section{LITERATURE CITED}

American Ornithological Union. 1998. American Ornithological Union checklist of North American birds, $7^{\text {th }}$ edition. A.O.U., Washington, D.C.

Ackerman, B. B., F. B. Leban, M. D. Samuel, and E. O. Garton. 1990. User's manual for program home range. College of Forestry, Wildl. Range Exp. Stn., Univ. Idaho, Moscow.

Anderson, D. J. 1982. The home range: a new nonparametric estimation technique. Ecology 63:103-112.

Boulanger, J. G., and G. C. White. 1990. A comparison of home-range estimators using Monte Carlo simulation. J. Wildl. Manage. 54:310-315.

Bowen, W. D. 1982. Home range and spatial organization of coyotes in Jasper National Park Alberta. J. Wildl. Manag. 46:201 -216.

Dixon, K. R., and J. A. Chapman. 1980. Harmonic mean measure of animal activity areas. Ecology 61:1040-1044.

Evans, P. R. 1988. Predation of intertidal fauna shorebirds in relation to time of the day, tide and year. Pages 65-78 in G. Chelazzi and M. Vannini, eds. Behavioral adaptation to intertidal life. Plenum Press, New York.

Hicklin, P. W., R. G. Hounsell, and G. H. Finney. 1989. Fundy pull trap: a new method of capturing shorebirds. J. Field Ornithol. 60:94-101.

Jandel Scientific. 1994. SigmaStat statistical software. User's Manual. Jandel Scientific, San Rafael, CA. 825pp.

Jennrich, R. I., and F. B. Turner. 1969. Measurement of non-circular home range. J. Theor. Biol. 22:227-237.

Kelly P. R., and H. L. Cogswell. 1979. Movements and habitat use by wintering populations of willets and marbled godwits. Stud. in Avian Biol. 2:69-82.

Luther, J. S. 1968. Populations and behavior of wintering marbled godwits in relation to tide cycles on Hayward Shore of San Francisco Bay. M.S. Thesis, California State College at Hayward.

Mech, D. L. 1983. Handbook of animal radio-tracking. Univ. Minnesota Press, Minneapolis.

Michener, G. R. 1979. Spatial relationships and social organization of adult Richardson's 
ground squirrels. Can. J. Zool. 57:125-139.

Millsap, B. A., J. Gore, D. E. Runde, and S. Cerulean. 1990. Setting priorities for the conservation of wildlife species in Florida. Wildl. Monogr. No. 111. 57pp. , and J. Feiertag. 1991. Coastal wildlife conservation plan. Florida Game and Fresh Water Fish Comm. Annu. Rep., Tallahassee. 18pp. + appendices.

Mohr, C. O. 1947. Table of equivalent populations of North American small mammals. Am. Midl. Nat. 37:223-249.

Myers, J. P. 1983. Conservation of migrating shorebirds: staging areas, geographic bottlenecks, and regional movements. Amer. Birds. 37:23-25.

Rappole, J. H. and A. R. Tipton. 1991. New harness design for attachment of radio transmitters to small passerines. J. Field ornithol. 62:335-337.

Robertson, W. B. Jr., and G. E. Woolfenden. 1992. Florida bird species: annotated list special publication no. 6 of Florida Ornithological Society Gainesville. 260 pp.

Sasser, L. D., K. L. Monroe, and J. N. Schuster. 1994. Soil survey of Franklin County, Florida. U.S. Dep. Agric.

Samuel, M. D., D. J. Pierce, and E. O. Garton. 1985. Identifying areas of concentrated use within the home range. J. Animal Ecology 54:711-719.

Smith, P. C. 1975. A study of the winter feeding ecology and behaviour of the Bar-tailed Godwit Limosa lapponica. Ph.D. Thesis, University of Durham, England.

Sprandel, G. L., and J. Gore. 1994. Winter shorebird survey: annual report. Florida Game and Fresh Water Fish Comm., Tallahassee. 111pp. + appendices.

, J. A. Gore, and D. T. Cobb. 1997. Winter shorebird survey. Florida Game and Fresh Water Fish Comm. Final Perf. Rep. Tallahassee. 162 pp. + vi.

Swihart, R. K., and N. A. Slade. 1986. The importance of statistical power when testing for independence in animal movements. Ecology 67:255-258.

Warnock, N. and S. Warnock. 1993. Attachment of radio-transmitters to sandpipers: review and methods. Wader Stud. Group Bull. 70:28-30.

White, G. C. and R. A. Garrott. 1990. Analysis of wildlife radio-tracking data. Academic Press, Inc., San Diego, Calif.

Wolfe, S. H., J. A. Reidenauer, and D. B. Means. 1988. An ecological characterization of 
the Florida Panhandle. U.S. Fish and Wildl. Serv. Biol. Rep. 88(12). 277pp.

Worton, B. J. 1987. A review of models of home range for animal movements. Ecol. Modelling 38:277-298. 
Table 1.1 Home range estimates for wintering shorebirds from December - February 1995-96 and 1996-97 in Lanark Reef shorebird complex, Franklin County, Florida.

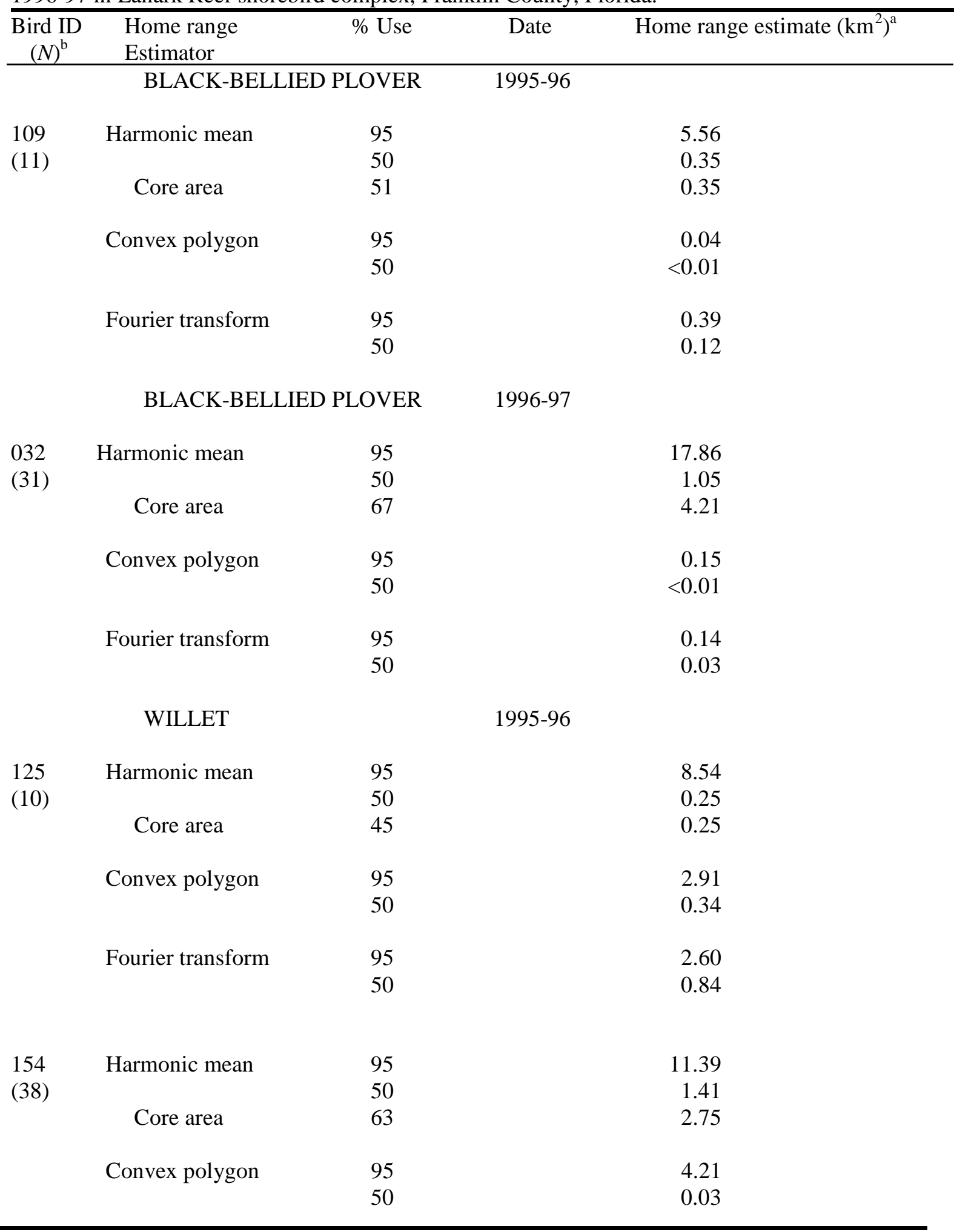


Table 1.1 Continued.

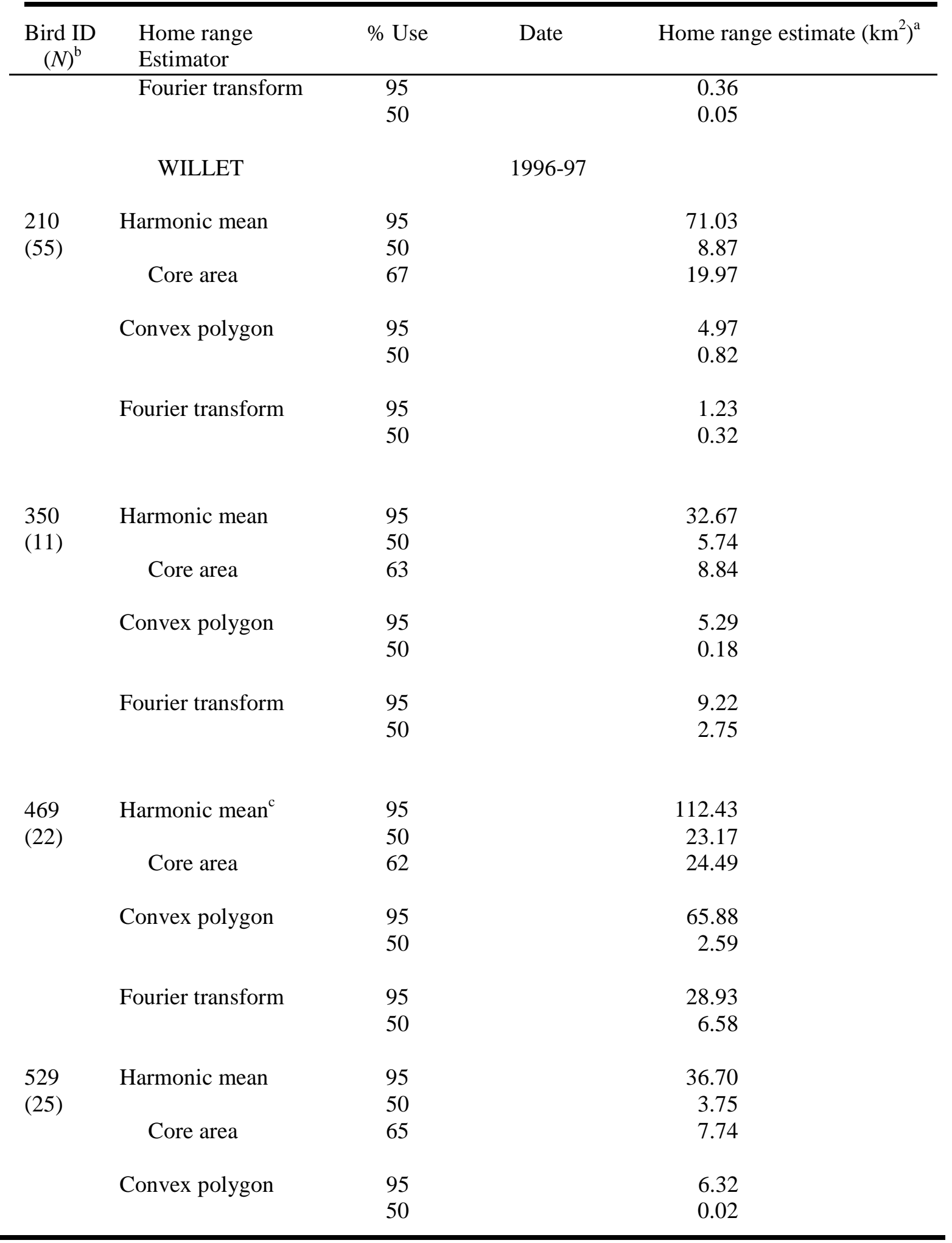


Table 1.1 Continued.

\begin{tabular}{|c|c|c|c|c|}
\hline $\begin{array}{l}\text { Bird ID } \\
(N)^{\mathrm{b}}\end{array}$ & $\begin{array}{l}\text { Home range } \\
\text { Estimator }\end{array}$ & $\%$ Use & Date & Home range estimate $\left(\mathrm{km}^{2}\right)^{\mathrm{a}}$ \\
\hline & Fourier transform & $\begin{array}{l}95 \\
50\end{array}$ & & $\begin{array}{l}2.45 \\
0.73\end{array}$ \\
\hline $\begin{array}{l}550 \\
(56)\end{array}$ & $\begin{array}{c}\text { Harmonic mean } \\
\text { Core area }\end{array}$ & $\begin{array}{l}95 \\
50 \\
59\end{array}$ & & $\begin{array}{r}32.79 \\
2.49 \\
9.01\end{array}$ \\
\hline & Convex polygon & $\begin{array}{l}95 \\
50\end{array}$ & & $\begin{array}{r}11.08 \\
1.10\end{array}$ \\
\hline & Fourier transform & $\begin{array}{l}95 \\
50\end{array}$ & & $\begin{array}{l}3.12 \\
0.83\end{array}$ \\
\hline $\begin{array}{l}572 \\
(16)\end{array}$ & $\begin{array}{c}\text { Harmonic mean } \\
\text { Core area }\end{array}$ & $\begin{array}{l}95 \\
50 \\
66\end{array}$ & & $\begin{array}{l}8.17 \\
0.17 \\
0.62\end{array}$ \\
\hline & Convex polygon & $\begin{array}{l}95 \\
50\end{array}$ & & $\begin{array}{r}10.89 \\
0.14\end{array}$ \\
\hline & Fourier transform & $\begin{array}{l}95 \\
50\end{array}$ & & $\begin{array}{l}1.63 \\
0.41\end{array}$ \\
\hline $\begin{array}{l}631 \\
(53)\end{array}$ & $\begin{array}{c}\text { Harmonic mean } \\
\text { Core area }\end{array}$ & $\begin{array}{l}95 \\
50 \\
66\end{array}$ & & $\begin{array}{r}100.01 \\
9.94 \\
24.56\end{array}$ \\
\hline & Convex polygon & $\begin{array}{l}95 \\
50\end{array}$ & & $\begin{array}{r}34.59 \\
1.21\end{array}$ \\
\hline & Fourier transform & $\begin{array}{l}95 \\
50\end{array}$ & & $\begin{array}{l}5.70 \\
1.04\end{array}$ \\
\hline $\begin{array}{l}651 \\
(43)\end{array}$ & $\begin{array}{c}\text { Harmonic mean } \\
\text { Core area }\end{array}$ & $\begin{array}{l}95 \\
50 \\
68\end{array}$ & & $\begin{array}{r}16.72 \\
2.27 \\
5.03\end{array}$ \\
\hline & Convex polygon & $\begin{array}{l}95 \\
50\end{array}$ & & $\begin{array}{l}2.36 \\
0.08\end{array}$ \\
\hline & Fourier transform & $\begin{array}{l}95 \\
50\end{array}$ & & $\begin{array}{l}0.51 \\
0.14\end{array}$ \\
\hline
\end{tabular}


Table 1.1 Continued.

\begin{tabular}{|c|c|c|c|c|}
\hline $\begin{array}{l}\text { Bird ID } \\
(N)^{\mathrm{b}}\end{array}$ & \multicolumn{4}{|l|}{ Estimator } \\
\hline \multirow{4}{*}{$\begin{array}{l}310 \\
(27)\end{array}$} & \multicolumn{2}{|c|}{ MARBLED GODWIT } & \multicolumn{2}{|l|}{ 1996-97 } \\
\hline & \multirow[t]{2}{*}{ Harmonic mean } & 95 & & 49.51 \\
\hline & & 50 & & 6.89 \\
\hline & Core area & 66 & & 11.56 \\
\hline & Convex polygon & 95 & & 6.72 \\
\hline & & 50 & & 0.32 \\
\hline & Fourier transform & 95 & & 4.14 \\
\hline & & 50 & & 1.24 \\
\hline & LONG-BILLE & RLEW & $1996-97$ & \\
\hline 189 & Harmonic mean & 95 & & 46.05 \\
\hline (58) & & 50 & & 3.87 \\
\hline & Core area & 61 & & 11.57 \\
\hline & Convex polygon & 95 & & 24.41 \\
\hline & & 50 & & 0.36 \\
\hline & Fourier transform & 95 & & 2.31 \\
\hline & & 50 & & 0.46 \\
\hline
\end{tabular}

${ }^{\mathrm{a}}$ All the harmonic mean calculations use the following parameters: grid points: $\mathrm{x}=35 ; \mathrm{y}=16$; plot scale: $1500 \mathrm{~m}=1 "$.

${ }^{\mathrm{b}} N=$ sample size

${ }^{\mathrm{c}}$ Harmonic mean parameters: grid points: $\mathrm{x}=35$; $\mathrm{y}=16$; plot scale: $3500 \mathrm{~m}=1$ ". 
Table 1.2 Comparison of standardized grid points to computer generated grid points for determining harmonic mean home range estimates for shorebirds in the Lanark Reef shorebird complex, Franklin County, Florida, December 1995 - February 1996 and December 1996 - February 1997. ${ }^{a}$

\begin{tabular}{|c|c|c|c|c|}
\hline \multirow[t]{2}{*}{ Bird } & \multicolumn{2}{|c|}{ Grid Points } & \multicolumn{2}{|c|}{ Harmonic Mean Estimate $\left(\mathrm{km}^{2}\right)$} \\
\hline & $\mathrm{x}$-axis & $y$-axis & $95 \%$ & $50 \%$ \\
\hline \multicolumn{5}{|c|}{ Black-bellied Plover: 1995-96 } \\
\hline \multirow[t]{2}{*}{109} & 35 & 16 & 5.5 & 0.3 \\
\hline & 72 & 32 & 2.4 & 0.1 \\
\hline \multicolumn{5}{|c|}{ Black-bellied Plover: 1996-97 } \\
\hline \multirow[t]{2}{*}{032} & 35 & 16 & 17.9 & 1.0 \\
\hline & 72 & 32 & 10.6 & 0.5 \\
\hline \multicolumn{5}{|c|}{ Willet: 1995-96 } \\
\hline \multirow[t]{2}{*}{125} & 35 & 16 & 8.5 & 0.2 \\
\hline & 49 & 22 & 6.3 & 1.5 \\
\hline \multirow[t]{2}{*}{154} & 35 & 16 & 11.4 & 1.4 \\
\hline & 31 & 14 & 13.9 & 1.5 \\
\hline \multicolumn{5}{|c|}{ Willet: 1996-97 } \\
\hline \multirow{2}{*}{210} & 35 & 16 & 71.0 & 8.9 \\
\hline & 56 & 25 & 52.2 & 6.8 \\
\hline \multirow[t]{2}{*}{350} & 35 & 16 & 32.7 & 5.7 \\
\hline & 20 & 9 & 74.2 & 12.0 \\
\hline \multirow[t]{2}{*}{469} & 35 & 16 & 112.4 & 23.2 \\
\hline & 32 & 14 & 109.1 & 13.9 \\
\hline \multirow[t]{2}{*}{529} & 35 & 16 & 36.7 & 3.7 \\
\hline & 42 & 19 & 30.9 & 3.5 \\
\hline \multirow[t]{2}{*}{550} & 35 & 16 & 32.8 & 2.5 \\
\hline & 72 & 32 & 33.7 & 0.05 \\
\hline \multirow[t]{2}{*}{572} & 35 & 16 & 8.2 & 0.2 \\
\hline & 35 & 15 & 9.4 & 0.4 \\
\hline \multirow[t]{2}{*}{631} & 35 & 16 & 100.0 & 9.9 \\
\hline & 39 & 17 & 92.8 & 7.6 \\
\hline \multirow[t]{2}{*}{651} & 35 & 16 & 16.7 & 2.3 \\
\hline & 72 & 32 & 13.3 & 2.5 \\
\hline \multicolumn{5}{|c|}{ Marbled godwit: 1996-97 } \\
\hline \multirow[t]{2}{*}{310} & 35 & 16 & 49.5 & 6.9 \\
\hline & 41 & 18 & 37.8 & 4.4 \\
\hline \multicolumn{5}{|c|}{ Long-billed curlew: 1996-97 } \\
\hline \multirow[t]{2}{*}{189} & 35 & 16 & 46.0 & 3.9 \\
\hline & 51 & 23 & 34.7 & 4.1 \\
\hline
\end{tabular}

${ }^{\text {a }}$ Standardized grid points: $\mathrm{x}$-axis $=35, \mathrm{y}$-axis $=16$. 
Table 1.3 Maximum distance between telemetric locations for wintering shorebirds from December February 1995-96 and 1996-97 in Lanark Reef shorebird complex, Franklin County, Florida.

\begin{tabular}{lcc}
\hline Species & $\begin{array}{c}\text { Identification } \\
\text { Number }\end{array}$ & Maximum distance $(\mathrm{km})$ \\
\hline Black-bellied Plover & 109 & 0.5 \\
Black-bellied Plover & 032 & 0.6 \\
Willet & 125 & 4.0 \\
Willet & 154 & 5.2 \\
Willet & 210 & 8.7 \\
Willet & 350 & 16.6 \\
Willet & 469 & 49.9 \\
Willet & 529 & 18.9 \\
Willet & 550 & 17.2 \\
Willet & 572 & 16.8 \\
Willet & 631 & 16.9 \\
Willet & 651 & 5.2 \\
Marbled Godwit & 310 & 23.8 \\
Long-billed Curlew & 189 & 18.1 \\
\hline
\end{tabular}




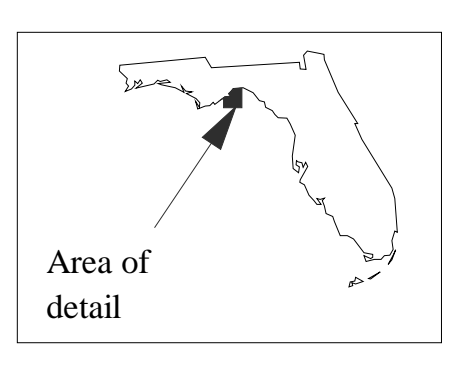

\section{WAKULLA COUNTY}

Shell Point

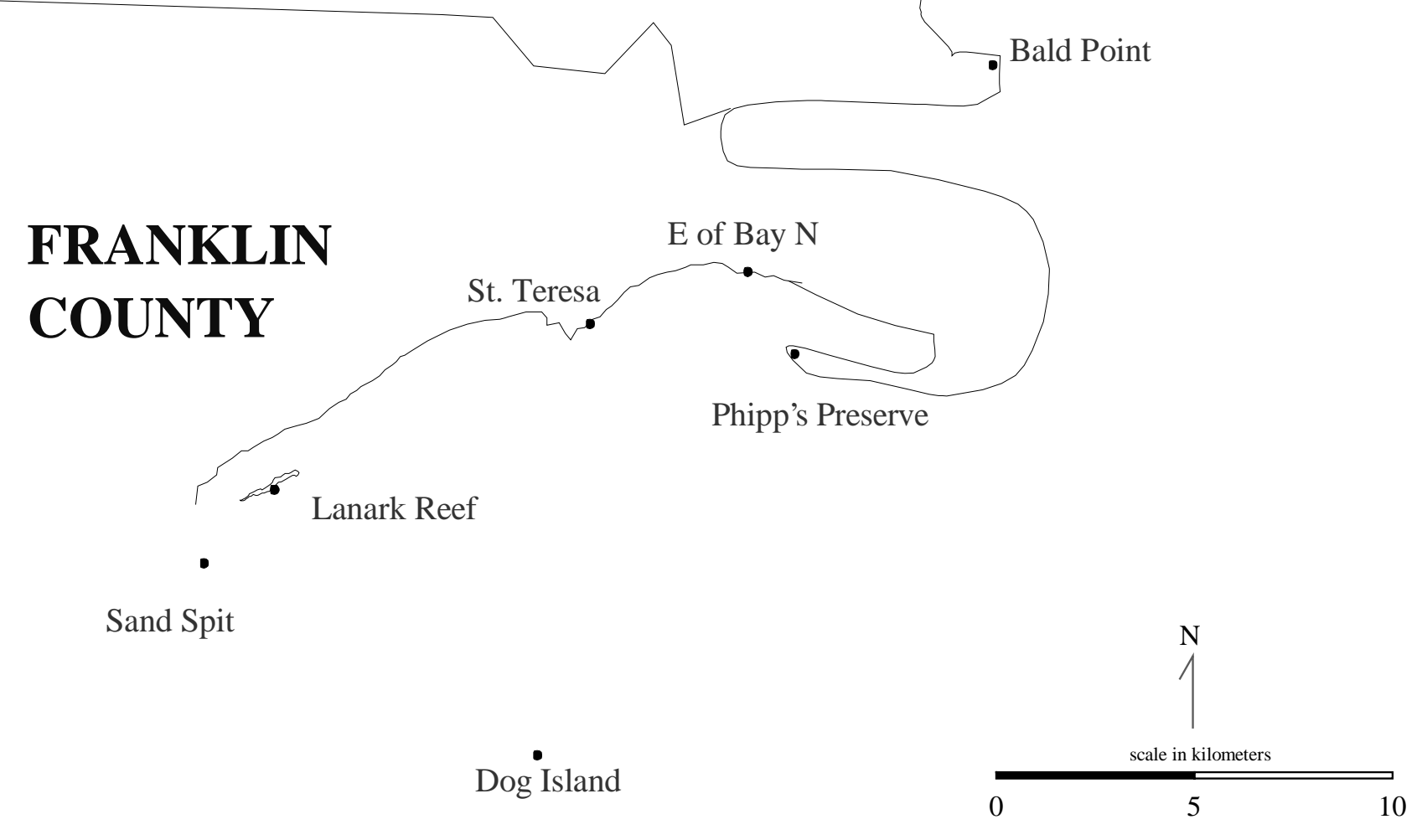

Figure 1.0 Lanark Reef Shorebird Complex, Franklin County, Florida 1995-97. 


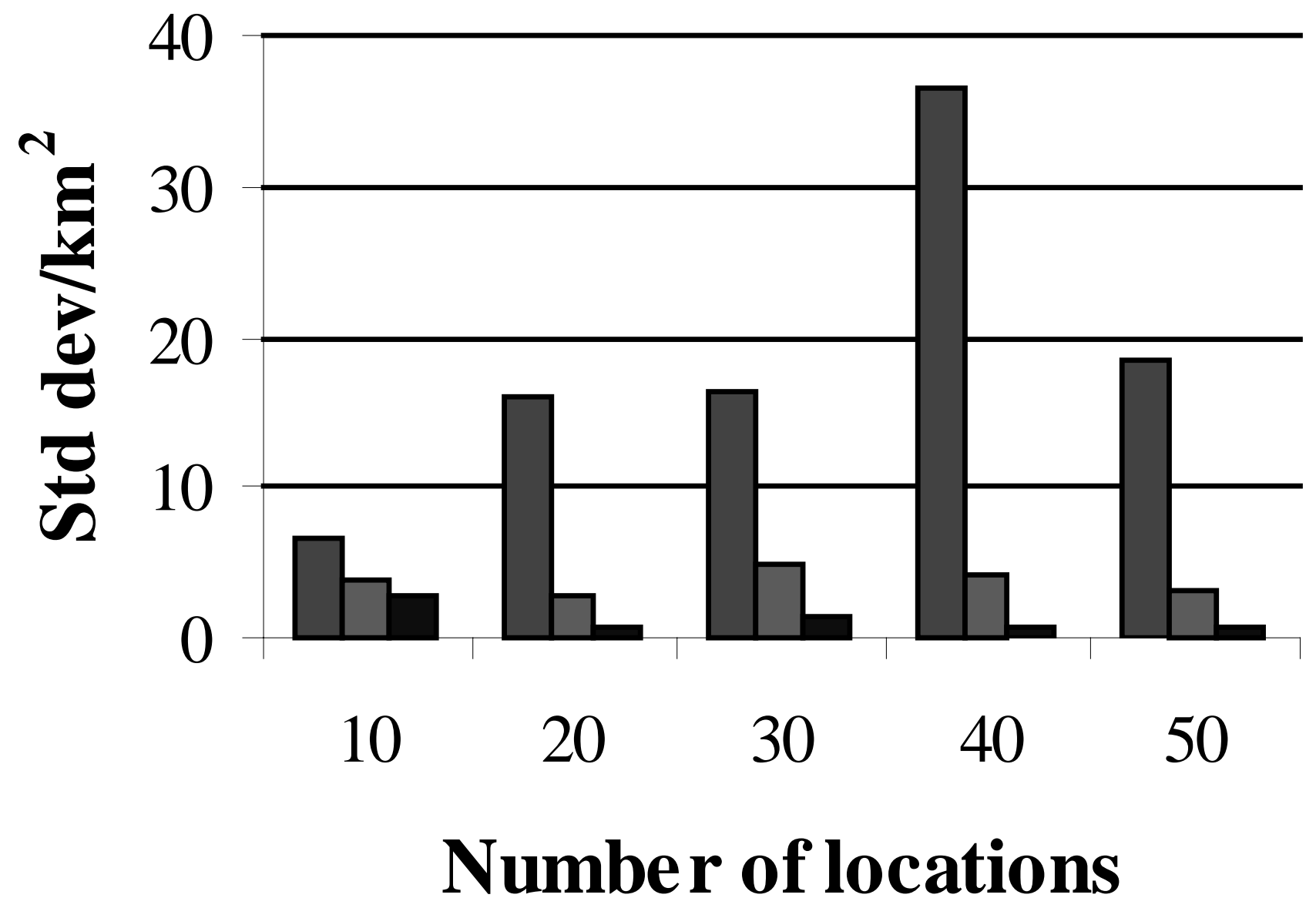

$\square$ harmonic mean

$\square$ convex polygon

$\square$ fourie $\mathrm{r}$ transform

Figure 1.2 Inherent variation within each home range estimate using Willet 550's telemetry locations, collected in the Lanark Reef Shorebird Comnlex Franklin County Florida Decemher 1096 to Fehruarv 1097 


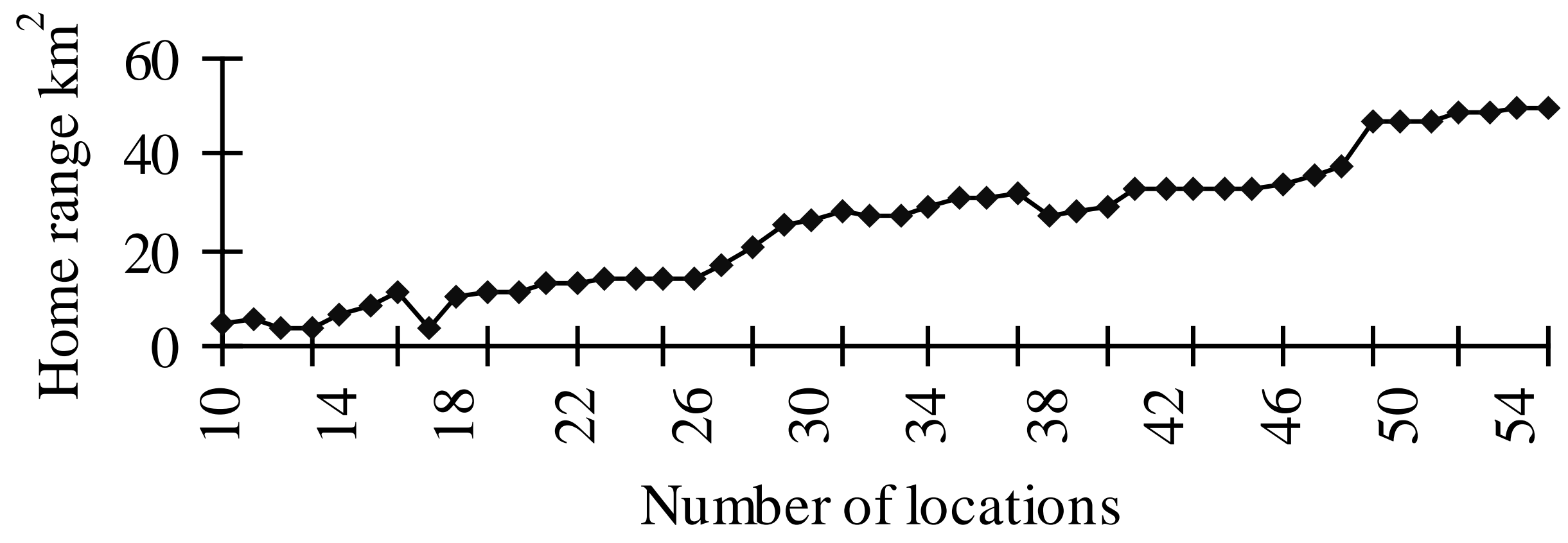

Figure 1.3 Increase in 95\% harmonic mean home range estimate with increasing number Willet 550's radio telemetry locations, collected in the Lanark Reef Shorebird Complex, Franklin County, Florida, December 1995 to February 1996. 


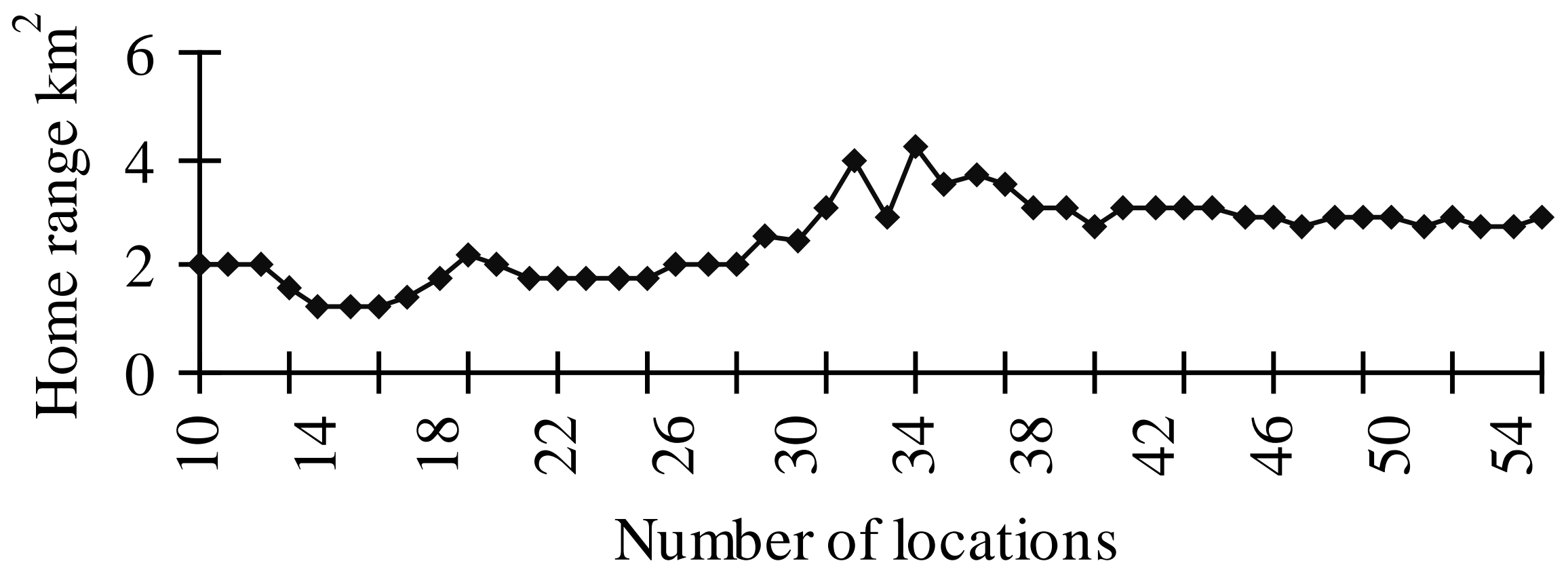

Figure 1.4 Increase in 95\% Fourier transform home range estimate with increasing number of Willet 550's radio telemetry locations, collected in the Lanark Reef Shorebird Complex, Franklin County, Florida, December 1995 to February 1996. 


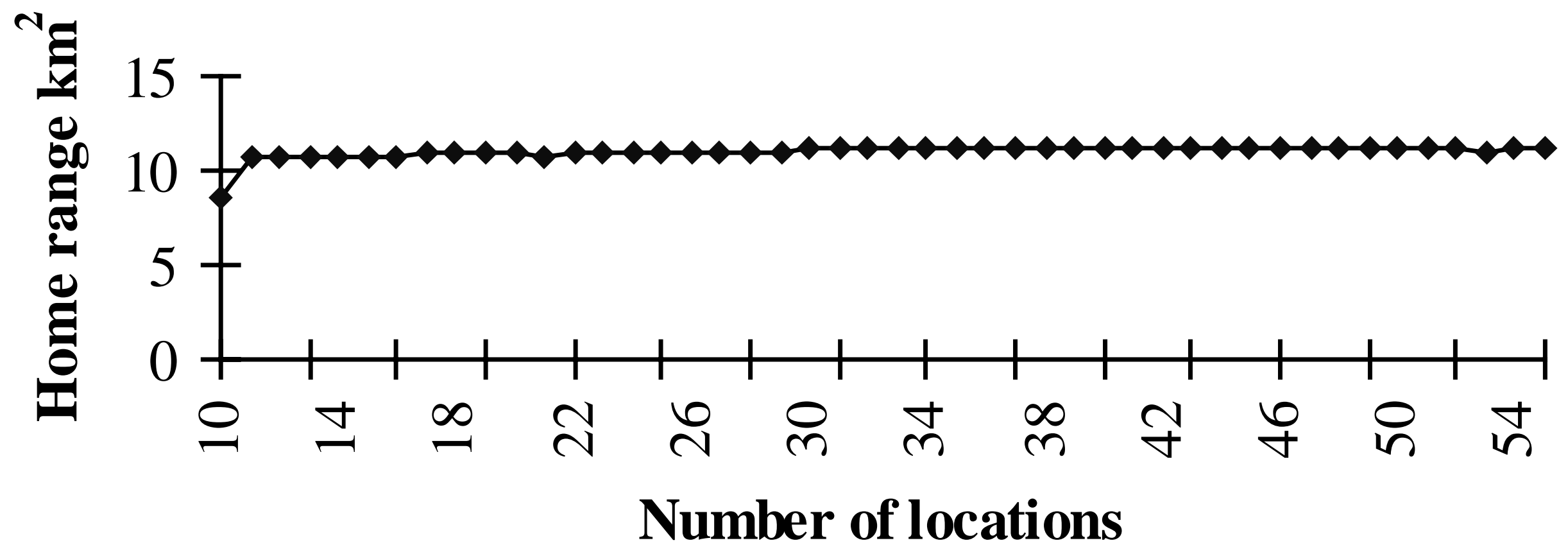

Figure 1.5 Increase in 95\% convex polygon home range estimate with increasing number of Willet 550's radio telemetry locations, collected in the Lanark Reef Shorebird Complex, Franklin County, Florida, December 1995 to February 1996. 


\section{Observations \\ Medium tide, $\mathrm{n}=8$ \\ High tide, $n=3$}

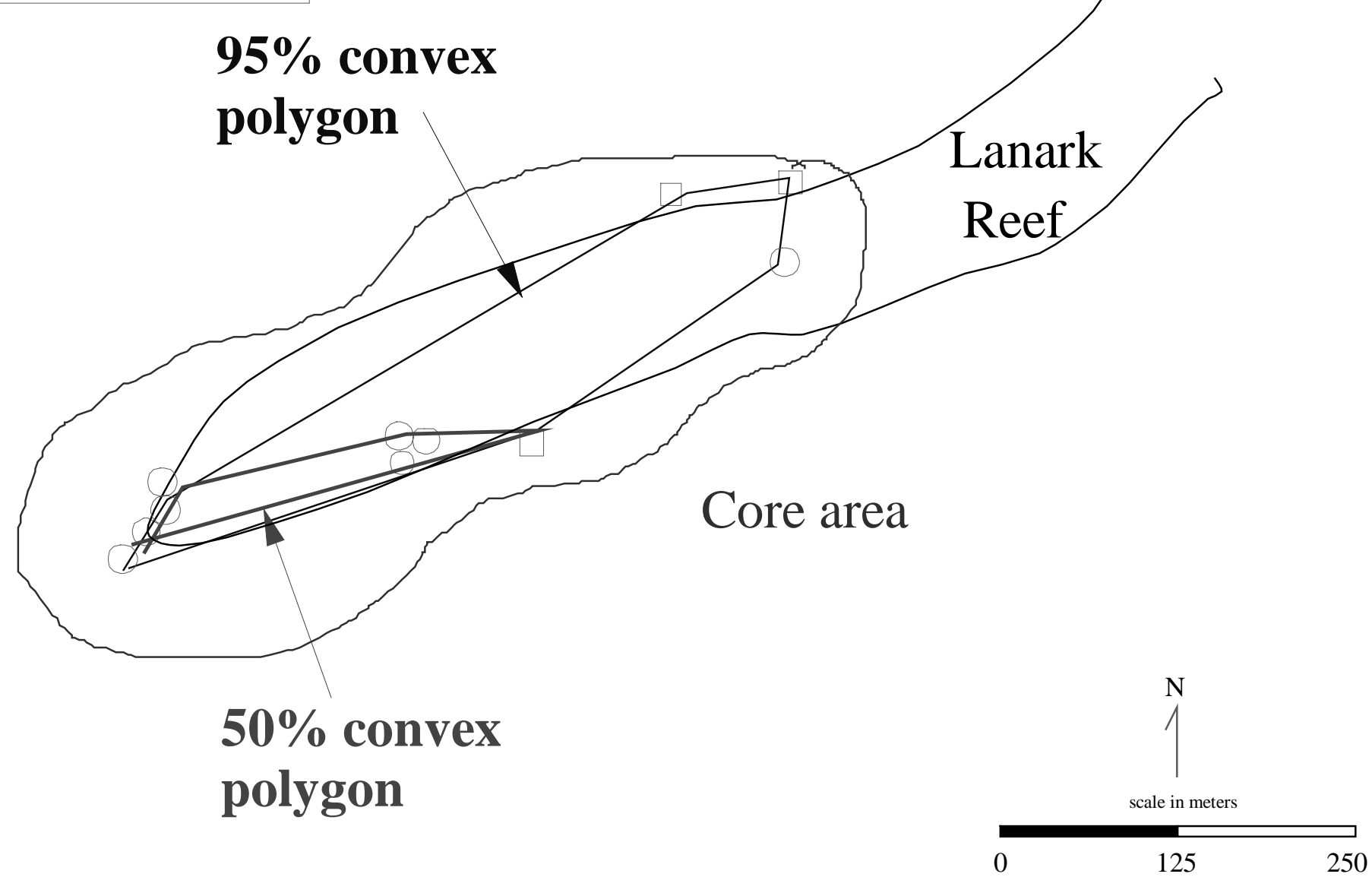

Figure 1.6 The 50\% and 95\% convex polygon home ranges and core area for Black-bellied Plover 109 based on telemetric observations in Franklin Co., Florida 2 December 1995 - 20 February 1996. 


\begin{tabular}{|l} 
Low tide, $\mathrm{n}=8$ \\
Medium tide, $\mathrm{n}=16$ \\
\\
High tide, $\mathrm{n}=7$
\end{tabular}

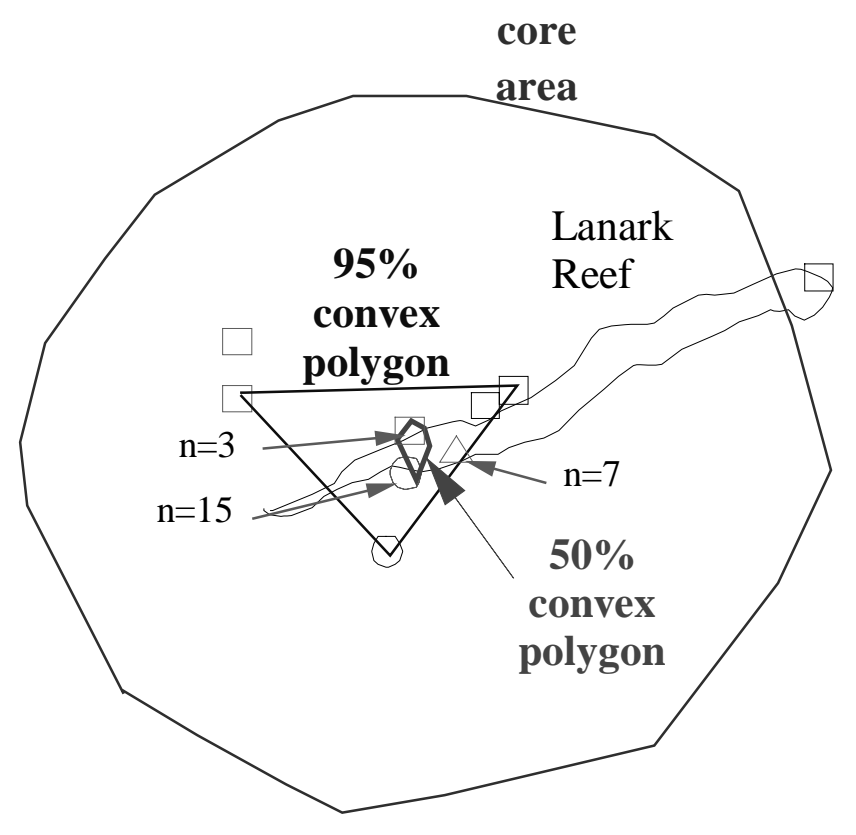

Sand

Spit

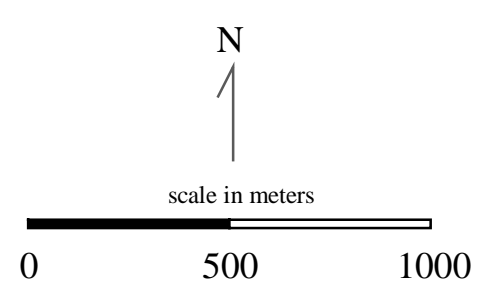

Figure 1.7 The 50\% and 95\% convex polygon home range and core area for Black-bellied Plover 032, based on telemetric locations in Franklin Co., Florida 6 December 1996 - 27 January 1997. 


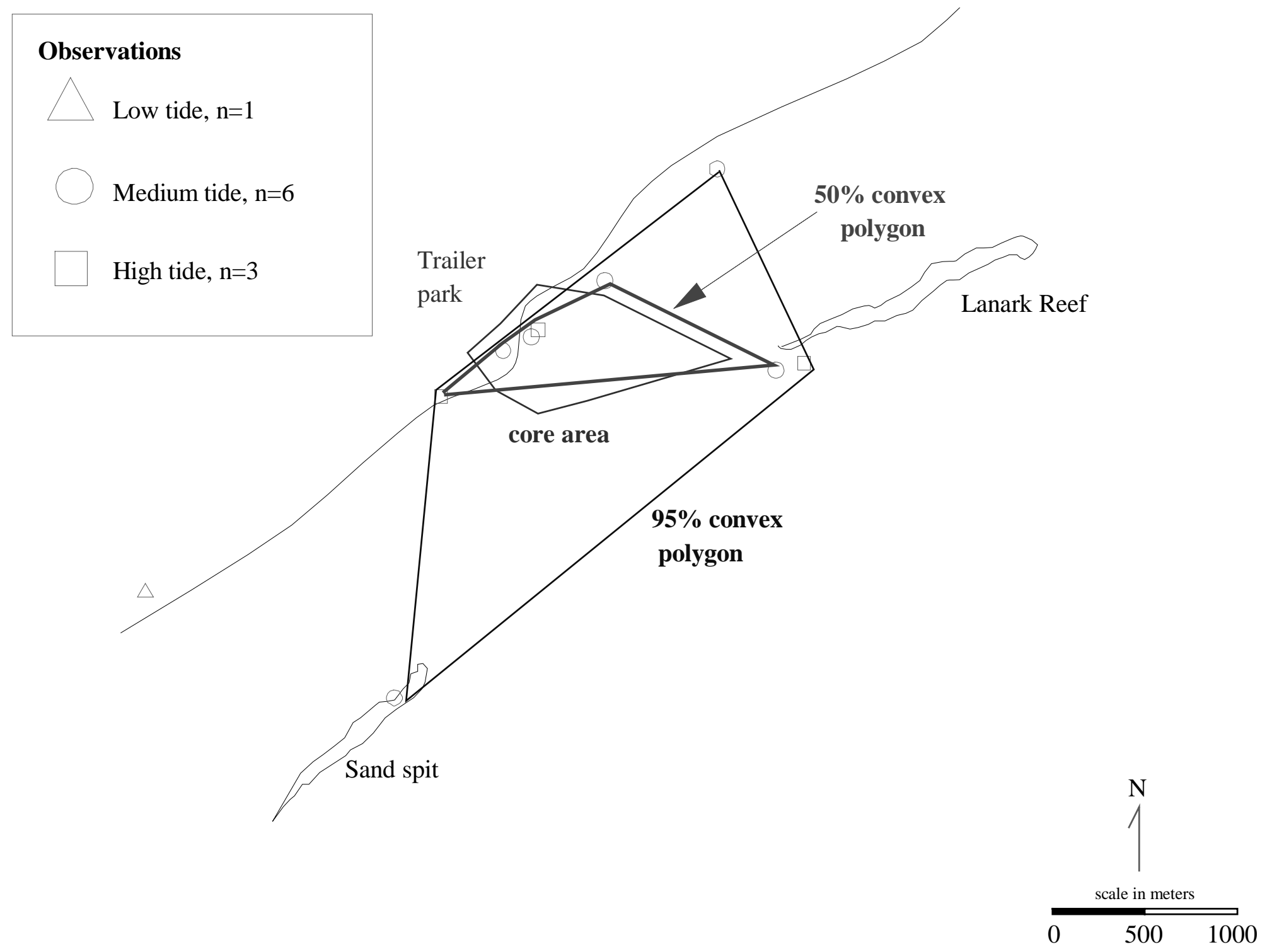

Figure 1.8 The 50\% and 95\% convex polygon home range and core area for Willet 125 based on telemetric locations in Franklin Co., Florida 1 December 1995 - 30 December 1995. 


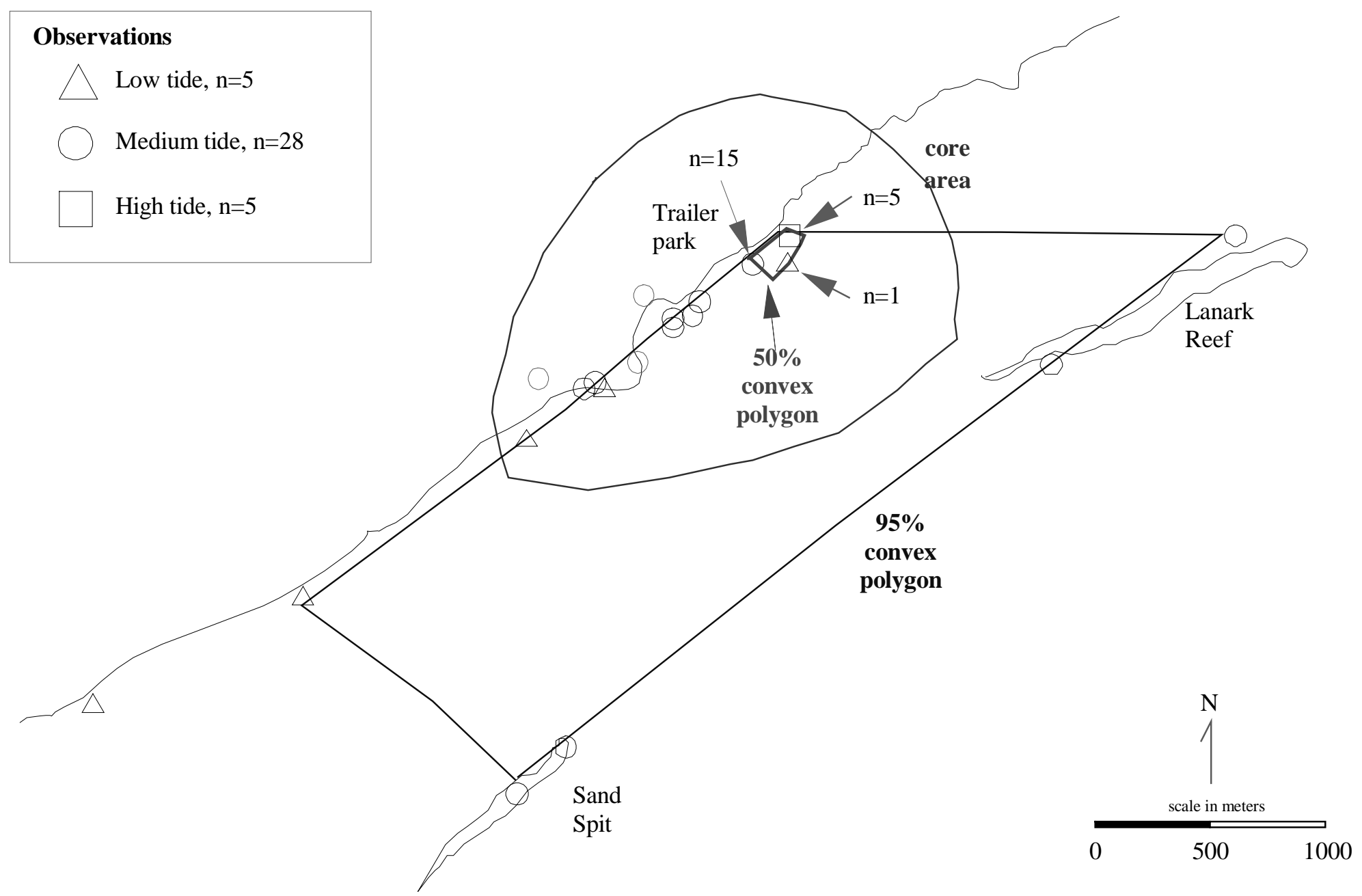

Figure 1.9 The 50\% and 95\% convex polygon home range and core area for Willet 154, based on telemetric locations in Franklin Co., Florida 14 December 1995 - 4 March 1996. 


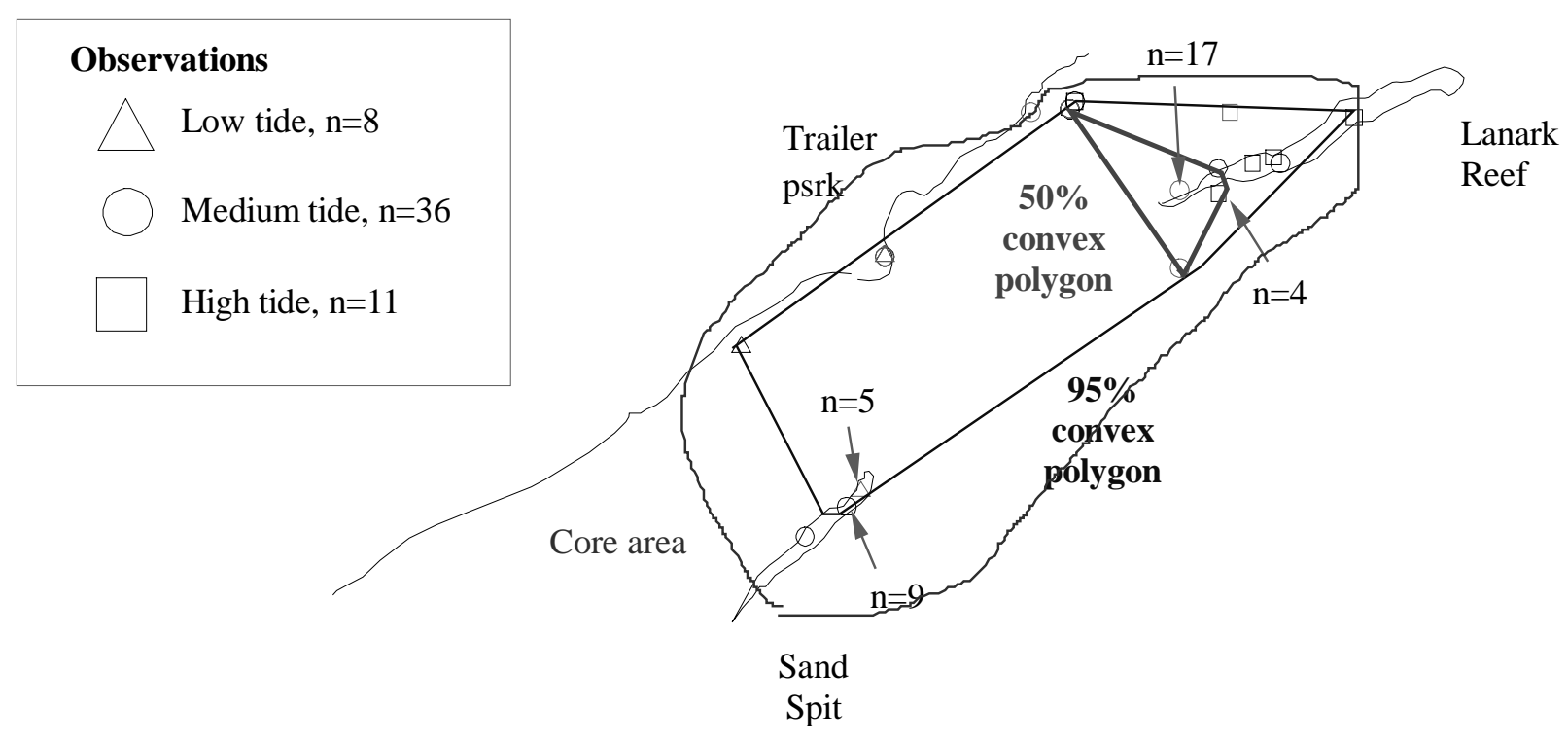

Figure 1.10 The 50\% and 95\% convex polygon home range for Willet 210, based telemetric observations in Franklin Co., Florida 5 December 1996 - 25 February 1997. 


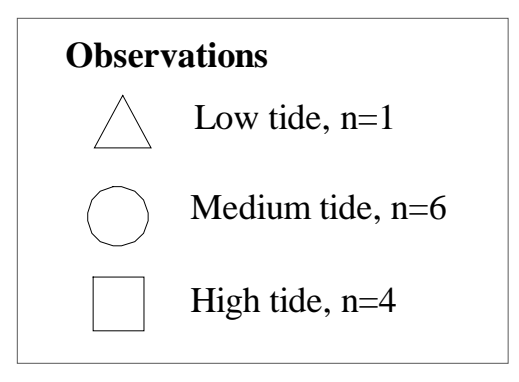

$\begin{array}{ll}\text { William's } & \text { East of Bay } \\ \text { Beach } & \text { North }\end{array}$

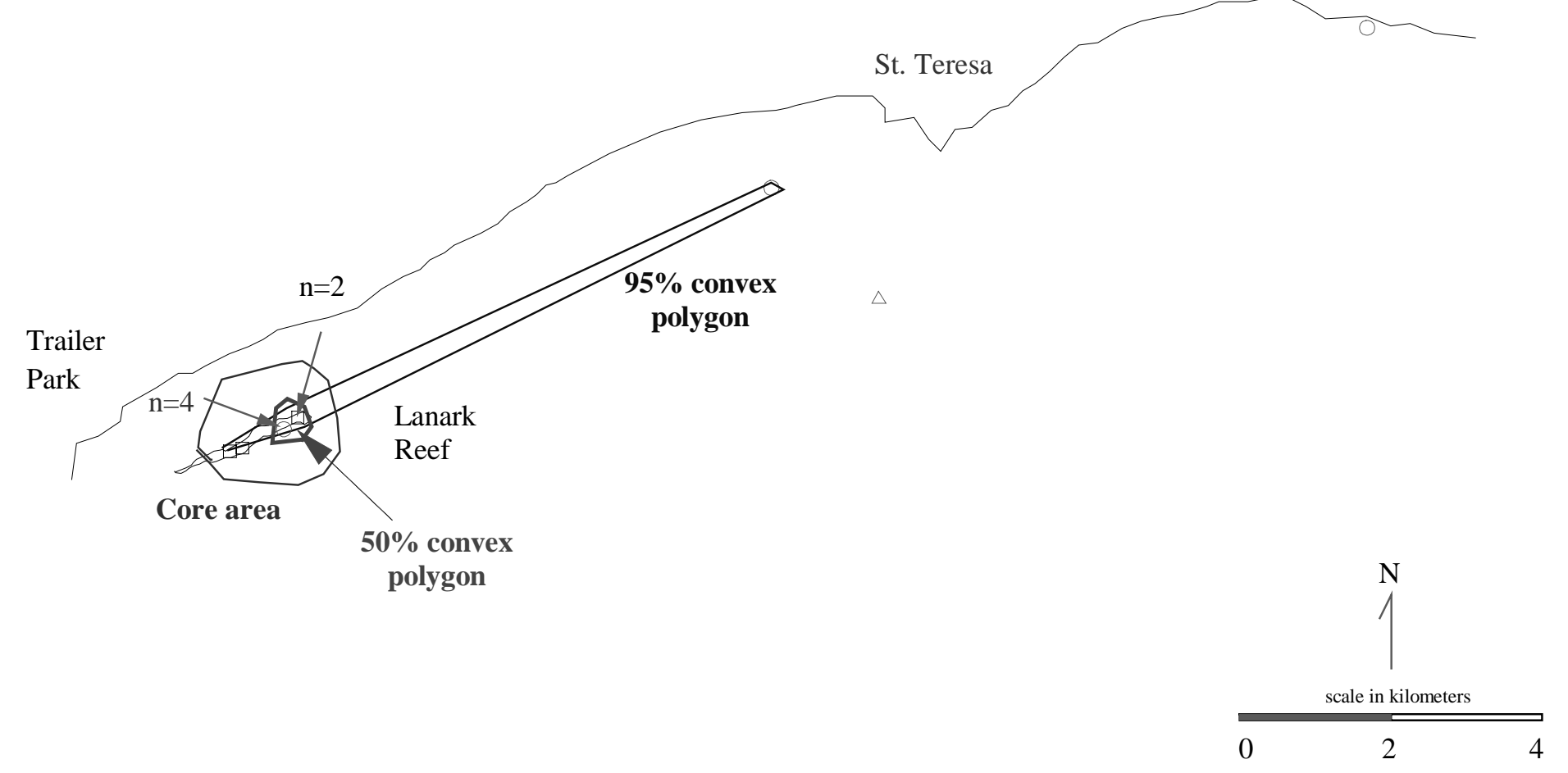

Figure 1.11 The 50\% and 95\% convex polygon home range and core area of Willet 350, based on telemetric locations in Franklin Co., Florida 5 December 1996 - 13 January 1997. 


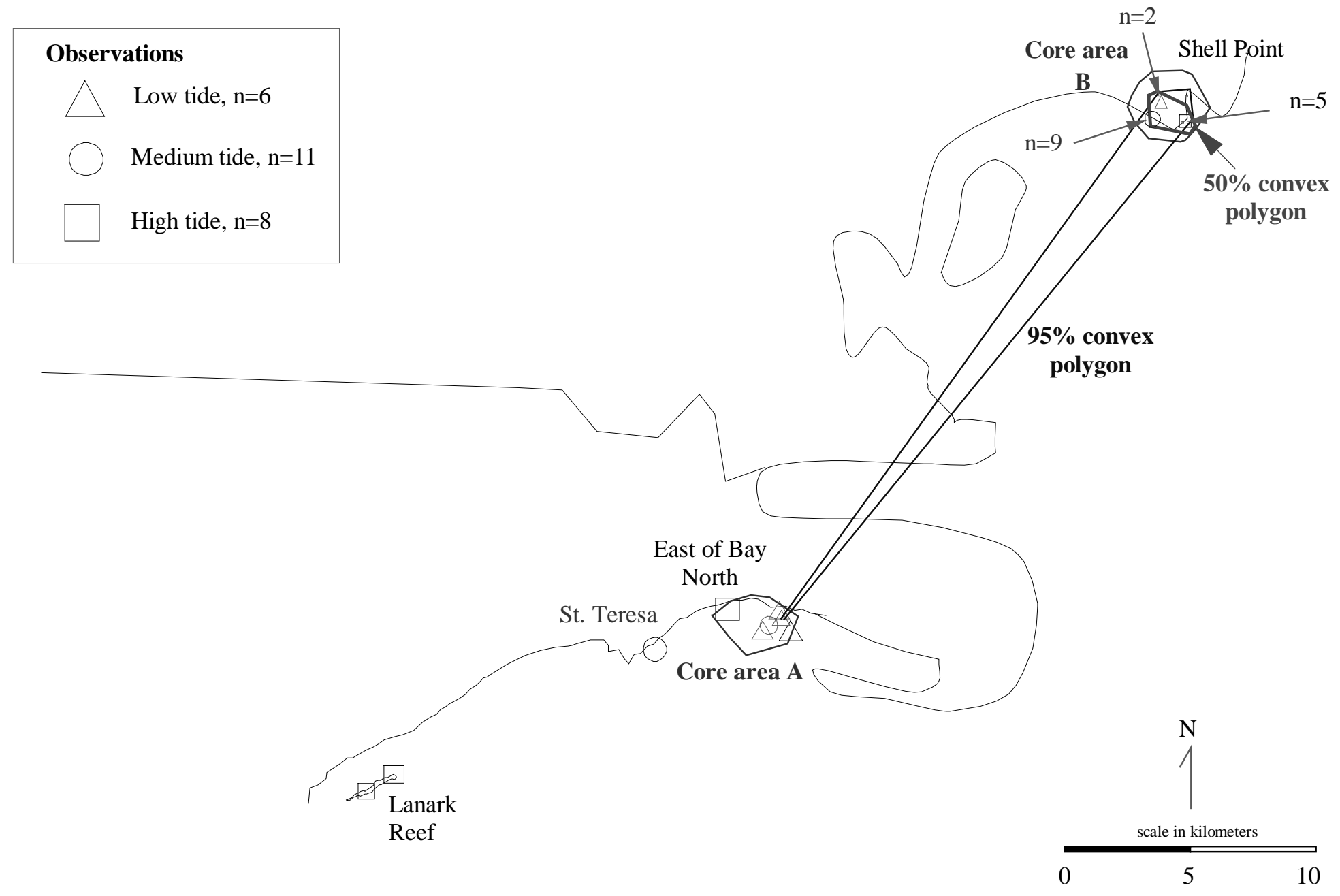

Figure 1.12 The $50 \%$ and $95 \%$ convex polygon home range and core area of Willet 469 , based on telemetric locations in Franklin Co., Florida 1 December 1996 - 28 February 1997. 


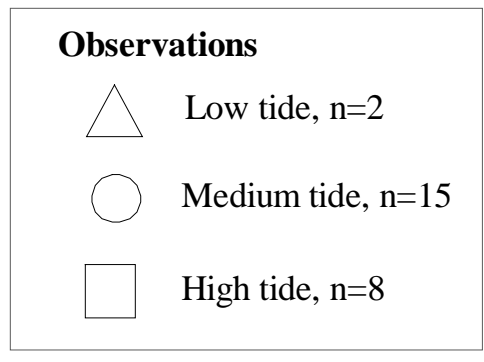

tide, $n=15$

h tide, $n=8$
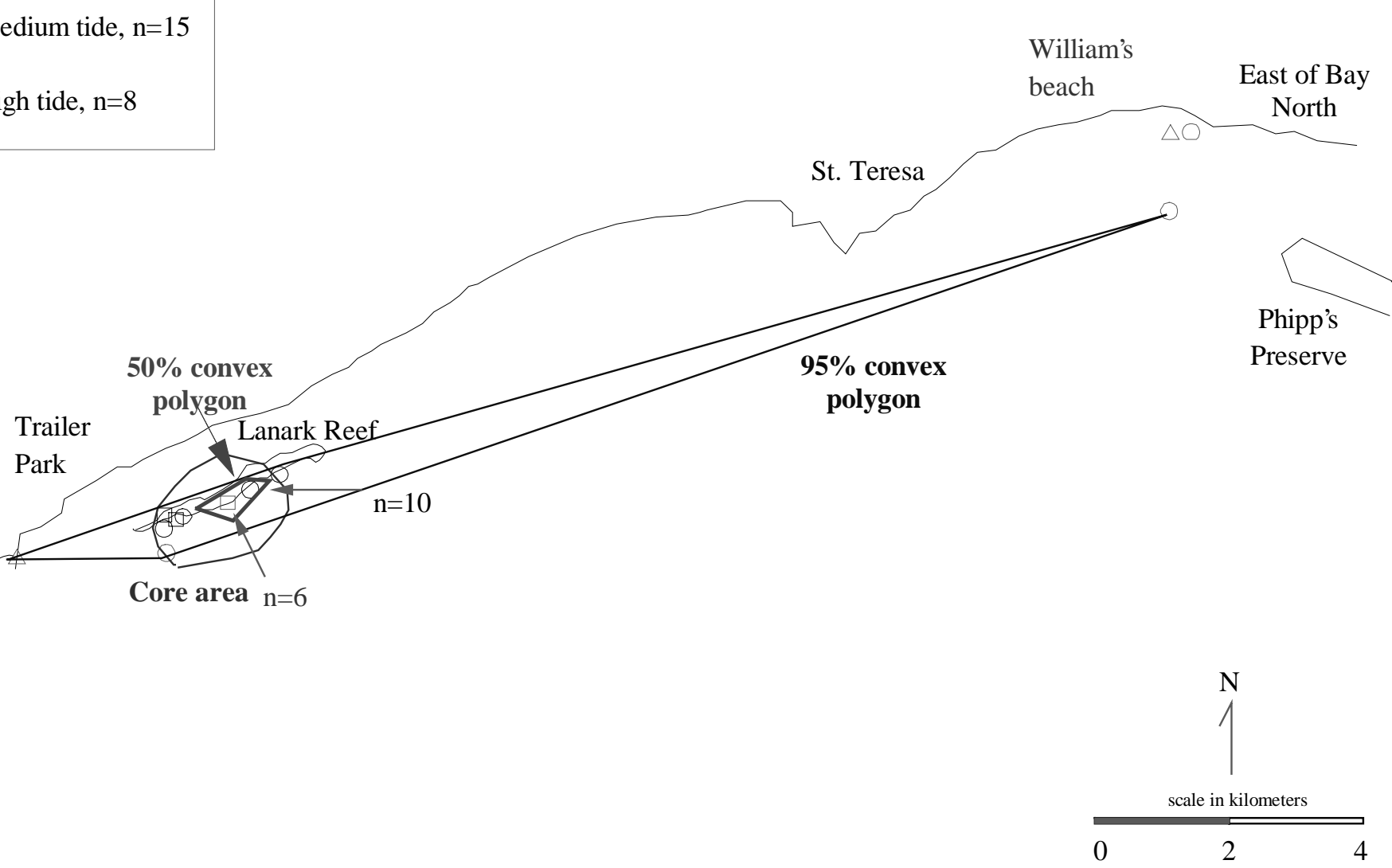

Figure 1.13 The 50\% and 95\% convex polygon home range and core area of Willet 529, based on telemetric locations in Franklin Co., Florida 11 December 1996 - 29 January 1997. 

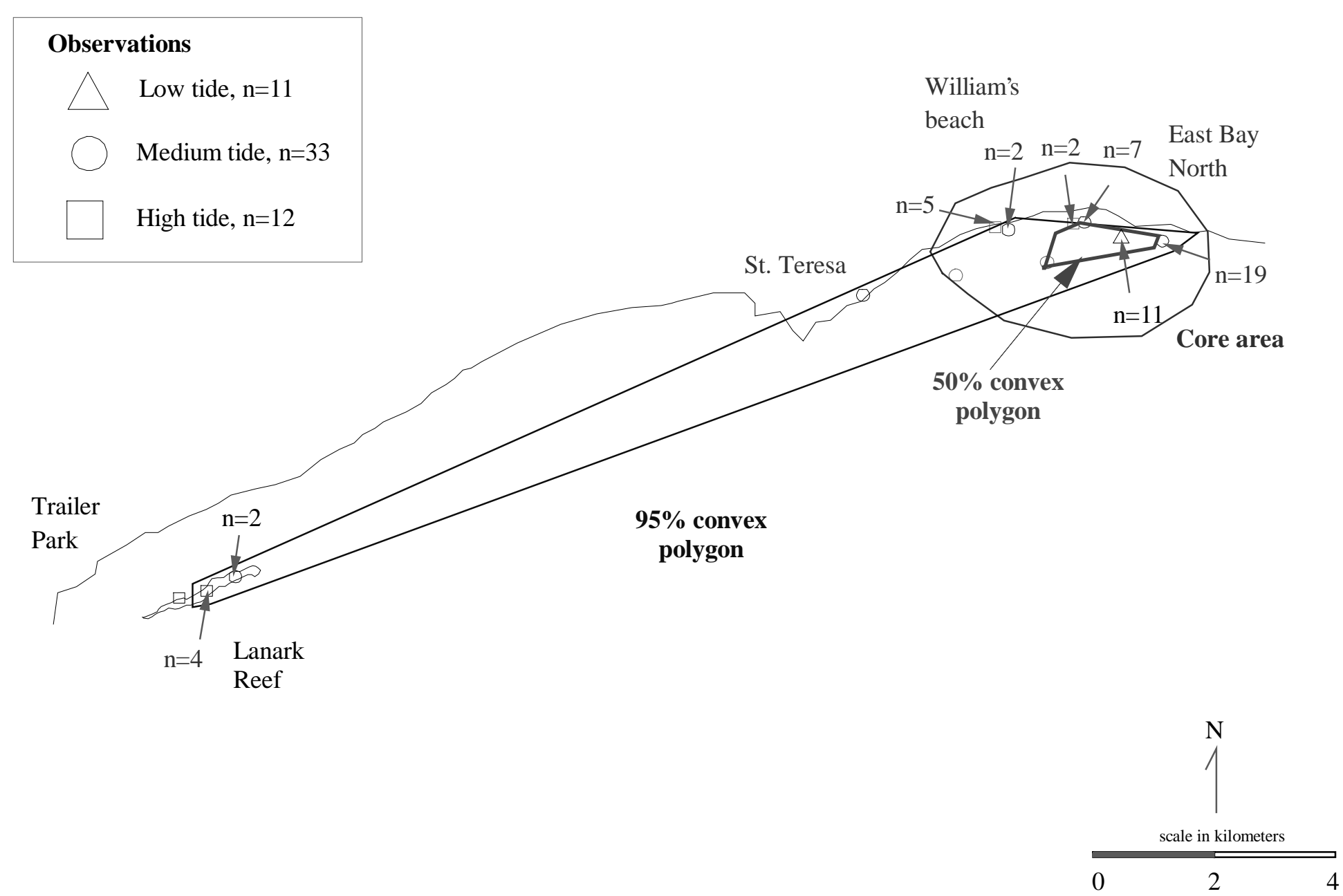

Figure 1.14 The 50\% and 95\% convex polygon home range and core area for Willet 550, based on telemetric locations in Franklin Co., Florida 11 December 1996 - 28 February 1997. 


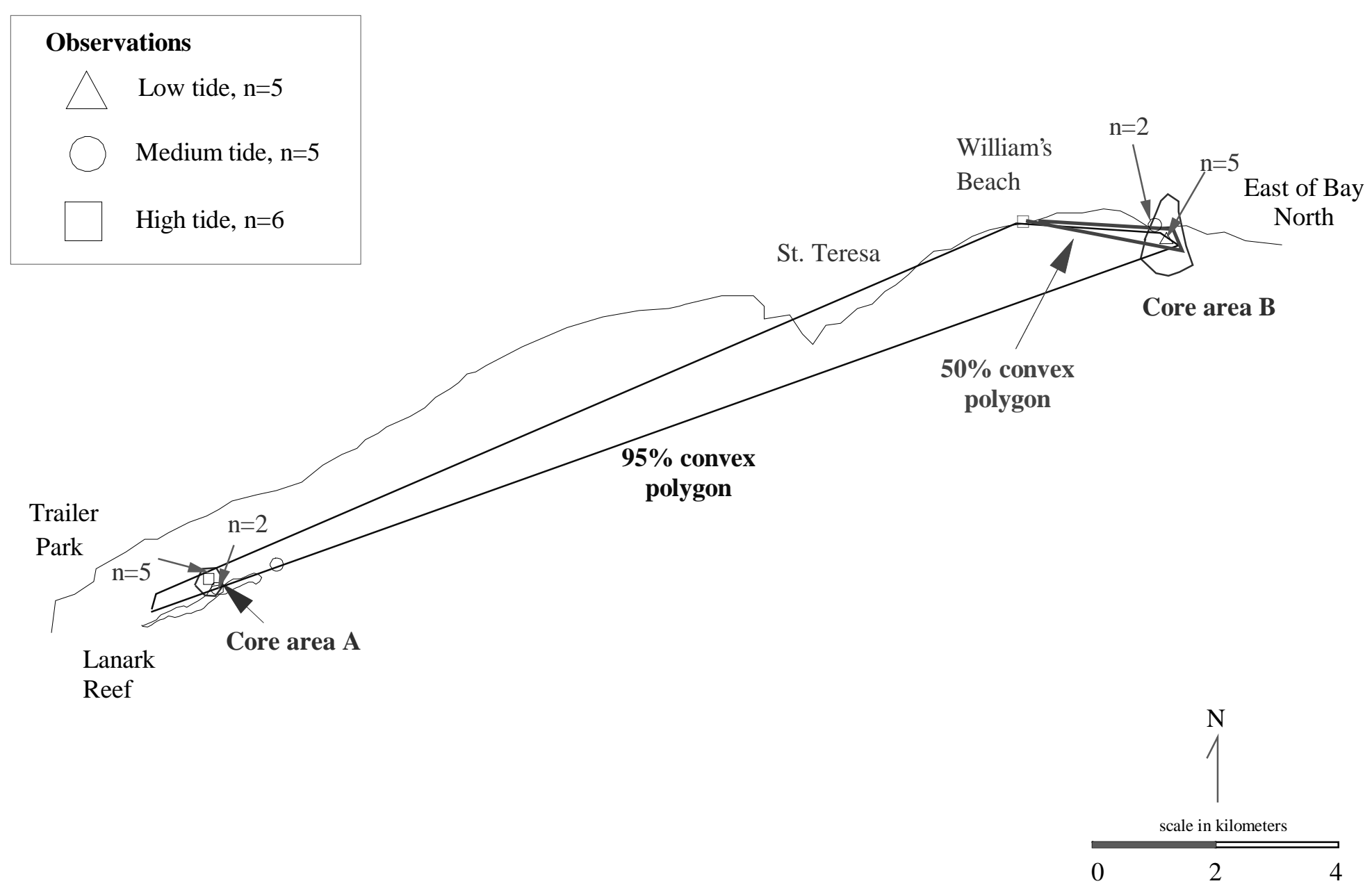

Figure 1.15 The 50\% and 95\% convex polygon home range and core areas for Willet 572, based on telmetric locations in Franklin Co., Florida 11 December 1996 - 23 January 1997. 

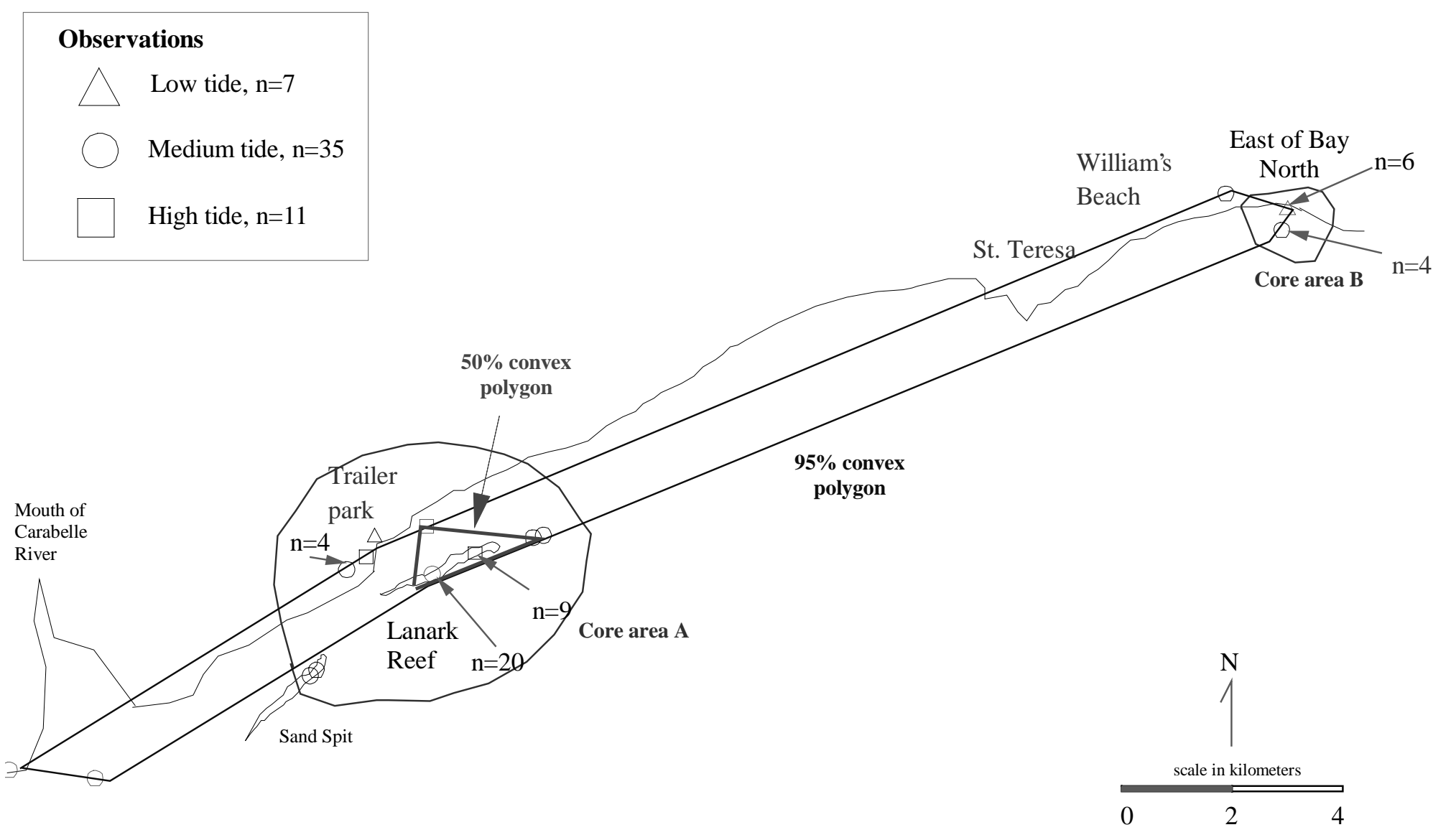

Figure 1.16 The 50\% and 95\% convex polygon home range and core areas for Willet 631, based on telemetric locations in Franklin Co., Florida 11 December 1996 - 27 February 1997. 


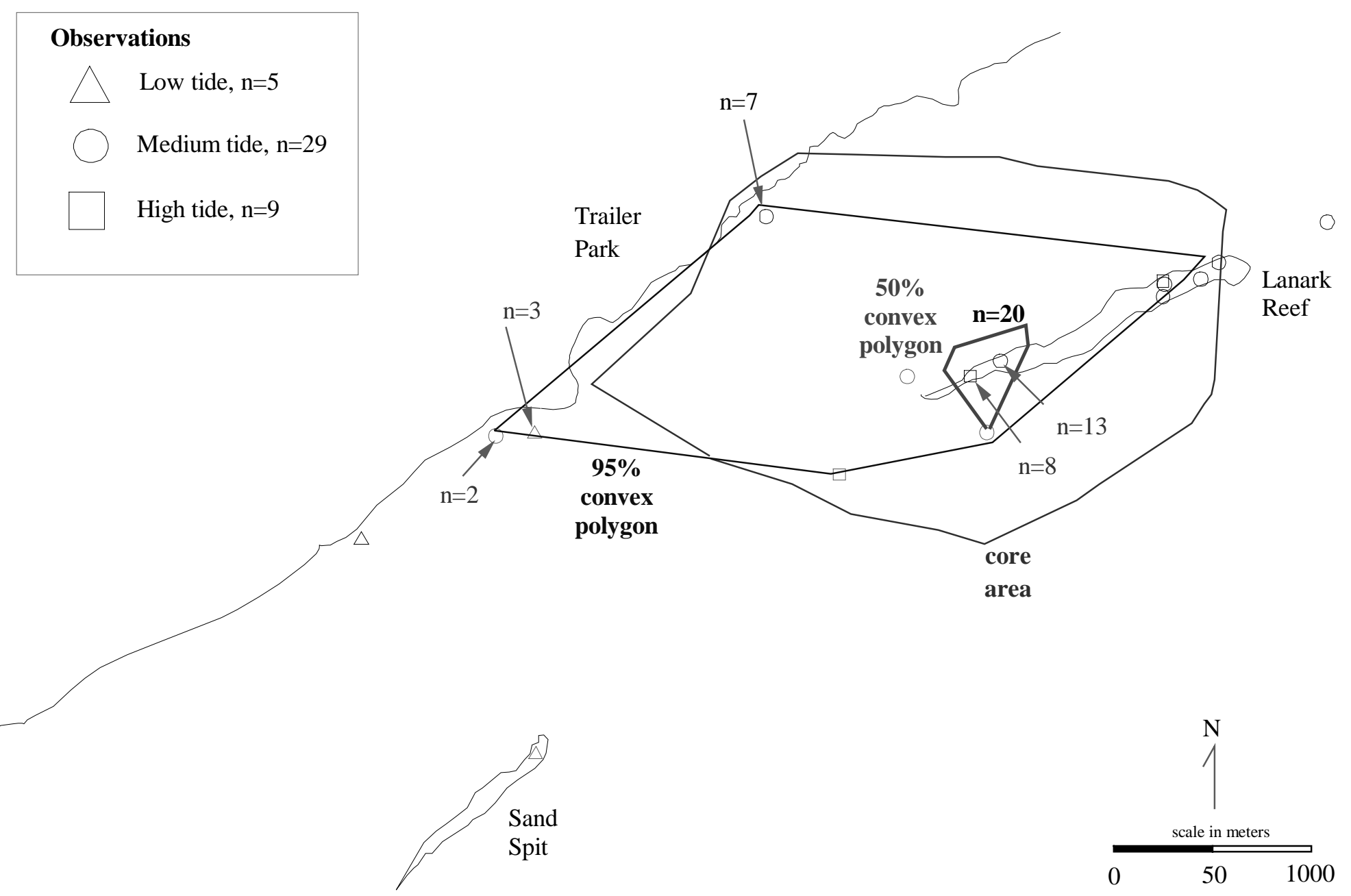

Figure 1.17 The 50\% and 95\% convex polygon home range and core area for Willet 651 based on telemetric locations in Franklin Co., Florida 6 December 1996 - 19 February 1997. 

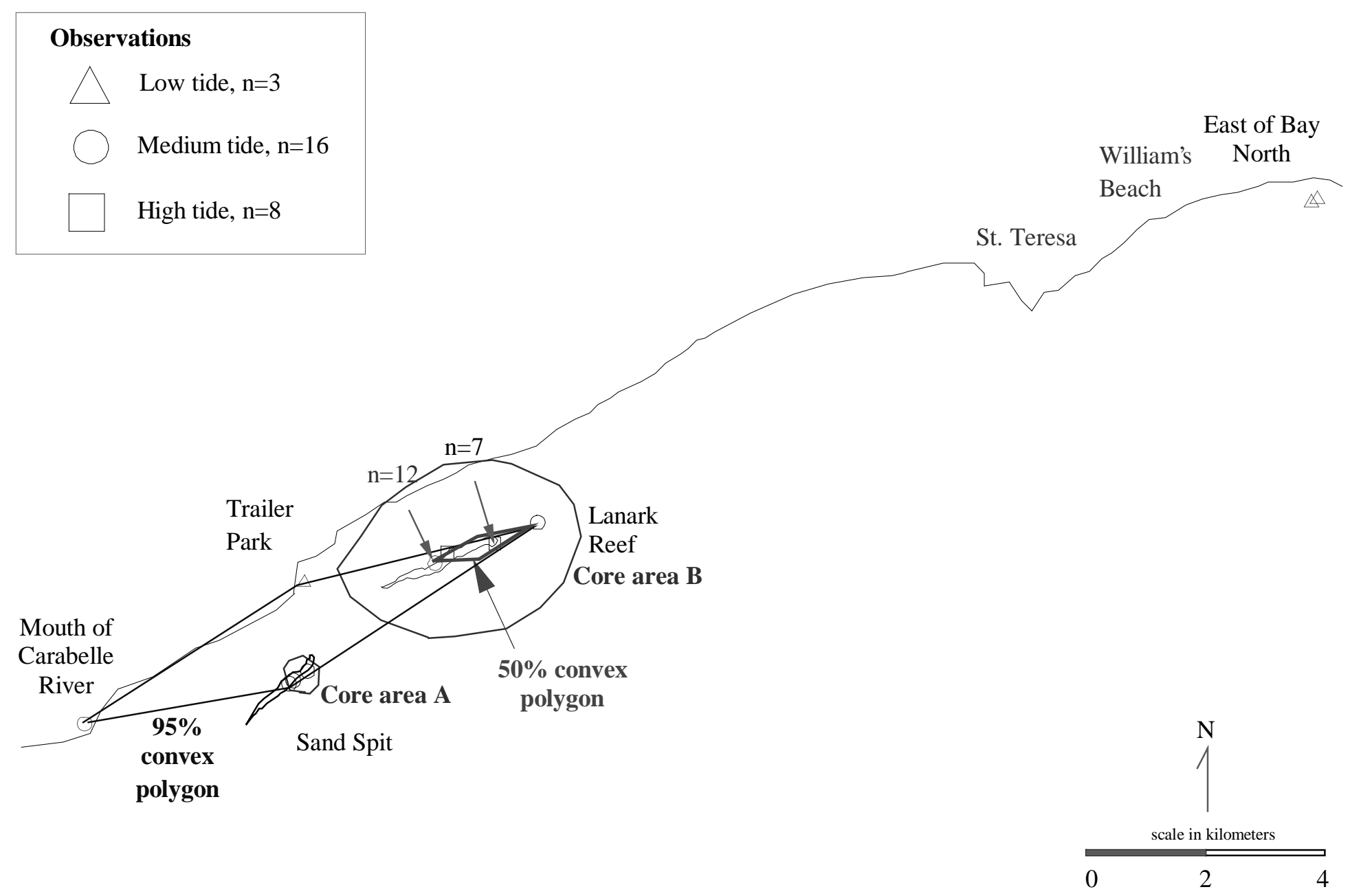

Figure 1.18 The 50\% and 95\% convex polygon home range and core areas for Marbled Godwit 310, based on telemetric locations in Franklin Co., Florida 11 December 1996 - 28 January 1997. 


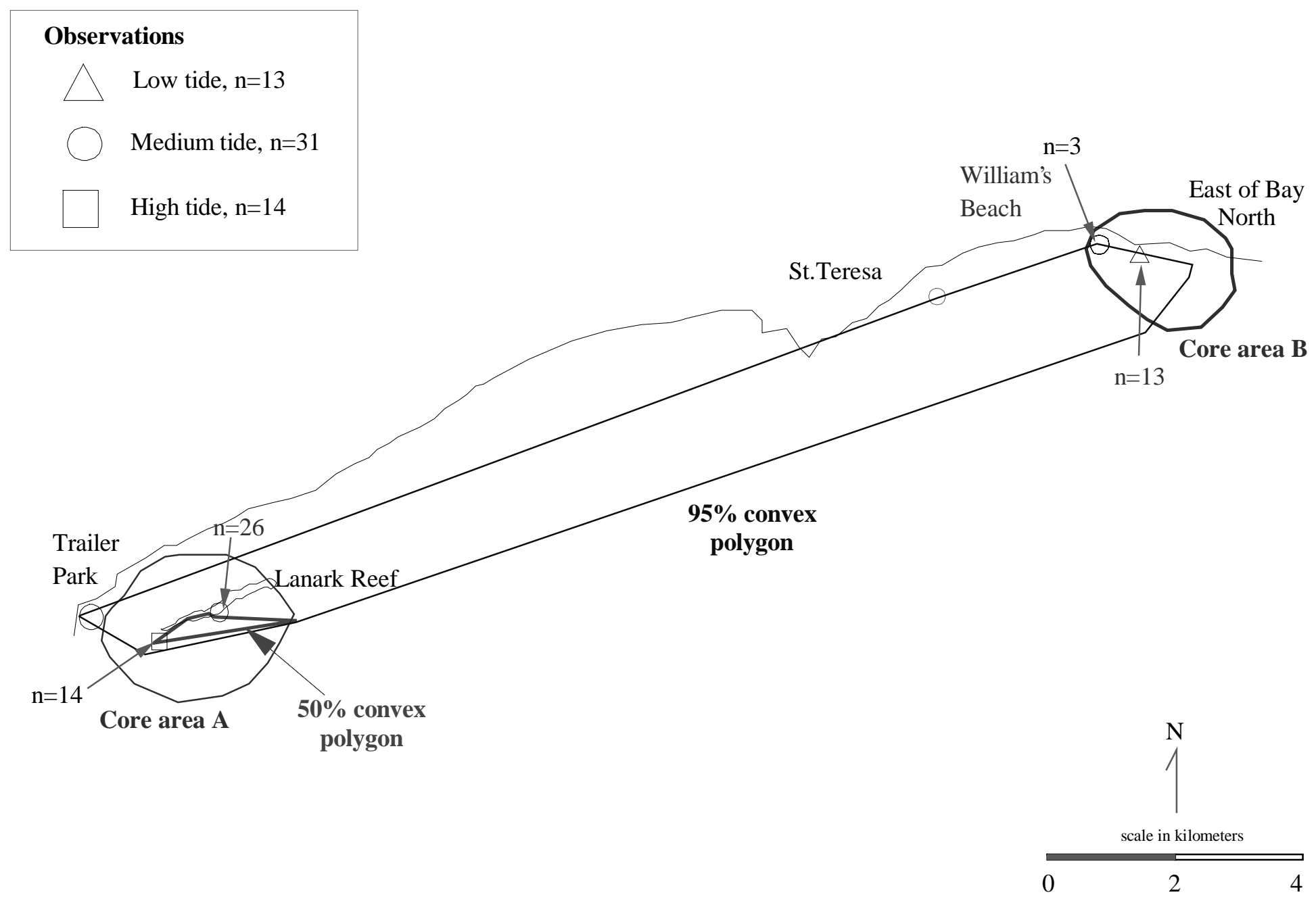

Figure 1.19 The 50\% and 95\% convex polygon home range and core areas for Long-billed Curlew 189, based on telemetric observations in Franklin Co., Florida 11 December 1996 - 27 February 1997. 


\section{Understanding Variation in Wintering Shorebird Count Data Christine Gunnels (ABSTRACT)}

In 1994, the Florida Game and Fresh Water Fish Commission conducted a statewide survey of wintering shorebirds and rated Lanark Reef as the most biologically important site in the state. The reef supports a combined average of 3.3\% of the Atlantic Flyway population. Of the wintering shorebirds in Florida, Lanark was used by $23.6 \%$ of the winter population for 5 species: Marbled Godwits (Limosa fedoa), American Oystercatchers (Haematopus palliatus), Snowy Plovers (Charadrius alexandrinus), Piping Plovers (C. melodus), and Willets (Catoptrophorus semipalmatus). Wintering sites used by shorebirds are fundamental in rebuilding and maintaining nutritional reserves necessary for spring migration and breeding. Replicate shorebird surveys were conducted on the reef and count data were regressed against four environmental variables (wind speed, tide height, cloud cover, and temperature). Regression results $\left(R_{a d j}^{2}\right)$ accounted for $45 \%$ and $66 \%$ of the variance in total shorebird counts on the Reef for 1996 and 1997, respectively. Shorebird total counts were positively correlated with tide height for 1996 and $1997(P<0.01)$. 


\section{Chapter 2 - Understanding Variation in Wintering Shorebird Count Data}

\section{INTRODUCTION}

Shorebird habitat is disappearing at an alarming rate (Myers 1983). The tendency of wintering shorebirds to congregate in large numbers at a limited number of sites makes them highly susceptible to disturbance and habitat degradation or loss. Forty-seven of 49 species of shorebirds that breed in North America live in Florida throughout the year (Robertson and Woolfenden 1992). In many areas human encroachment on critical shorebird habitat has become an increasing concern. Consequently, wintering shorebirds have been identified through longterm planning projects by the Florida Bureau of Nongame Wildlife as a group of coastal wildlife species for which conservation should be a priority (Millsap et al. 1990, 1991). Lanark Reef, a small island off the Florida panhandle, was rated by the Florida Game and Fresh Water Fish Commission the most biologically important high tide roosting site in Florida (Sprandel and Gore 1994).

Analyses of wintering shorebird survey data have shown that counts can have high variability among and between sites (Sprandel and Gore 1994). Highly variable count data can make it difficult for managers to monitor population trends. Variability in site use and shorebird count data collected at a particular site may be due to environmental conditions, spatial and temporal variation in food resources, stochastic or deterministic shorebird behavior, or random events (e.g., human disturbance, presence of predators, etc.). Results of a statewide survey indicated that there was a great deal of variation in count data at the reef (Sprandel et al. 1997). My objective was to examine previously collected shorebird count data in order to determine trends and sources of variability.

\section{STUDY AREA}

Lanark Reef is approximately $1 \mathrm{~km}$ off the coast of the Florida Panhandle in Franklin County (Fig. 2.1). The west-end is located west at $84^{0} 34.979$ and north at $29^{0} 52.416$. Human activity on the island is minimal. Once on the island, human presence was only obvious from litter which washed in with the tides, houses which could be seen on the mainland, and an occasional boats seen from the shore.

Habitat on the reef consisted of mostly sand flats (comprised of sand and shell fragments) with mud flats occurring at low tide on the eastern and western ends. The middle of the island is rather densely vegetated with seagrass (Thalassia spp.) and small succulent bushes (Salicornia spp) (Wolfe et al. 1988). Vegetation structural density decreases towards either end of the island (Fig. 2.2). The soil types found on the reef are Mandarin-Resota-Leon and Duckston sand (Sasser et al. 1994).

Dog Island is a barrier island located approximately $5 \mathrm{~km}$ to the south. The position of this island reduces storm surges, thus reducing erosion effects to Lanark Reef (Jim Ladner, FL Geological Survey, pers comm.). However, variable amounts of land are exposed during different tide heights. The reef is an isolated, stable island near a highly dynamic inter-tidal area, 
an optimal area to study use by wintering shorebirds.

\section{METHODS}

\section{Count Procedure}

The biologists were trained for shorebird counts by an expert ornithologist specializing in shorebird identification. Before the 1996 field season began, repeated shorebird identification trips were conducted to ensure accurate identification skills.

Lanark Reef was completely surveyed 30 times from 9 January 9 to 4 March 1996 and again from 9 January through 26 February 1997. Six survey areas were delineated, at naturally occurring breaks in the reef due to previous tidal inundation, by placing wooden stakes $50 \mathrm{~m}$ apart on an $180^{\circ}$ transect running north to south on the Reef (Fig. 2.2). Counts began at the north end of the wooden stakes between zones 3 and 4 . The reef was then surveyed in an east and west direction by attempting to count all shorebirds within each of the 6 zones.

Approximately 10-15 m distance was maintained from the birds to avoid disturbance while still maintaining an adequate view. Only birds on the ground were included in the survey. Birds that flew in after a flock or an area were counted were not included. Each shorebird was identified to species or, if unknown, classified in one of the following categories: small (e.g., small plovers, Dunlin [Calidris alpina], Sanderlings [C. alba], and Western Sandpipers [C. mauri]), medium (e.g., Red Knots [C. canutus] or Short-billed Dowitchers [Limnodromus griseus]), or large (e.g., Willets [Catoptrophorus semipalmatus] or Marbled Godwits [Limosa fedoa]) shorebird (names follow American Ornithological Union 1998).

\section{Environmental Data}

Before initiating counts in count area 3, tide, temperature, wind speed and direction, and time were recorded. Initially in 1996, tide height was measured at a buoy marking the channel leading out of the Village Fina marina. Subsequently, tide height was determined using a 3meter graduated PVC pipe attached to a pylon in the Village Fina marina. Thirteen tide heights were measured at the buoy marker outside the Village Fina marina, 10 heights were measured inside the marina, and 7 height measurements were collected at both locations. The 13 buoy heights were then transformed using the following regression equation: pylon height $=0.374+$ $(0.410 *$ buoy height $)\left(r^{2}=0.58, \alpha=0.05\right)$. In 1997 , the pylon holding the graduated PVC pipe from 1996 was removed from the marina. Consequently, a new PVC pipe was attached to the new pylon but it was not possible to standardize the tide heights between field seasons.

Wind speed $(\mathrm{km} / \mathrm{hr})$ was determined using a Dyer wind meter (Michigan City, Indiana 46360). Percent cloud cover was estimated on 4 random compass directions at $45^{\circ}$ above the horizon using a PVC pipe $14.5 \mathrm{~cm}$ long by $2.6 \mathrm{~cm}$ in diameter. The random compass directions were determined using a random number generator. These 4 estimates were then averaged to give a percent cloud cover for each day surveyed.

\section{Count Analyses}

All statistics were examined using SigmaStat ${ }^{\circledR}$ (Jandel Scientific 1994). Species specific summary statistics were calculated for the count data. Variation in shorebird counts 
were examined using a backward stepwise regression to determine the relationship between: tide height $(\mathrm{m})$, wind speed $(\mathrm{km} / \mathrm{hr})$, temperature $\left({ }^{\circ} \mathrm{C}\right)$, and percent cloud cover on total shorebird abundance. The best model had the lowest $P$ value and highest $R_{\text {adj }}^{2}$. Normality and independence among residuals was examined using the Kolmogorov - Smirnov test and the Durbin - Watson statistic, respectively.

Pearson Product Moment correlation was used to further examine the relationship between the environmental variables and total shorebird counts. In addition, I looked at simple qualitative relationships between bird counts and environmental variables to determine the reason for anomalies in abundance. Results from all analyses were used to determine which of the chosen variables attribute to the variation in shorebird counts.

\section{RESULTS}

Although time of counts among the count days was not standardized, counts generally lasted one and a half hours. The following species were observed in the counts: American Oystercatcher (Haematopus ostralegus), Marbled Godwit, Willet, Red Knot, Short-billed Dowitcher, Dunlin, Sanderling, Western Sandpiper, Ruddy Turnstone (Arenaria interpres), Black-bellied Plover (Pluvalis squatarola), and small plovers (including Piping [Charadrius melodus], Semipalmated [C. semipalmatus], Wilson [C. wilsonia], and Snowy [C. alexandrinus] Plovers). There was an average of $806(\mathrm{CV}=74 \%)$ and $1262(\mathrm{CV}=71 \%)$ total shorebirds counted on Lanark Reef for 1996 and 1997, respectively. The maximum number of shorebirds counted for 1996 and 1997 was 1,917 and 2,971, respectively. Average conditions for the 3 highest total counts for 1996 and 1997 were with average wind speed $=10.5 \mathrm{~km} / \mathrm{hr}, 51 \%$ cloud cover, tide height $=0.86 \mathrm{~m}$ in 1996 and $1.29 \mathrm{~m}$ in 1997, and temperature $=17.5 \mathrm{C}^{\mathrm{o}}($ Table 2.1). The minimum counts for 1996 and 1997 were 55 and 71, respectively. Average environmental conditions for the 3 lowest total counts in 1996 and 1997 were wind speeds $=8 \mathrm{~km} / \mathrm{hr}$, winds from the north to northeast, $42 \%$ cloud cover, tide height $=0.65 \mathrm{~m}$ in 1996 and $0.5 \mathrm{~m}$ in 1997 , and temperature $=14 \mathrm{C}^{\circ}$ (Table 2.1). Counts were conducted within the following tidal ranges: $0.53 \mathrm{~m}-1.2 \mathrm{~m}$ in 1996 and $0.32 \mathrm{~m}-1.5 \mathrm{~m}$ in 1997 .

Of the total birds counted in 1996 and 1997, 11\% and 12\% were counted during low tide, respectively. In contrast, $27 \%$ and 39\% of total birds were counted in 1996 and 1997 during high tide (Table 2.2). In 1996, total count data were positively correlated with tide height $(P \leq$ $0.0001 ; r=0.59$ ) (Table 2.3). Temperature, wind speed, and cloud cover were not significantly correlated with total count data $(P>0.05)$. In 1997, tide height and temperature were both positively correlated with total count data $(P<0.03 ; r=0.4$, temperature; $r=0.67$, tide) (Table 2.3). Average counts for most species were higher in 1997, although Western Sandpipers and small plovers were an exception (Figs. 2.3). On average, Dunlin were the most common species seen on the reef in 1996 and 1997. Interestingly, only 8-9\% of the total Dunlin counted were recorded during low tide for both field seasons. This was the lowest percentage at low tide, for all the species except for the Western Sandpiper (Table 2.2). Generally, as the tide rose so did the number of shorebirds counted. Most of the shorebirds were counted $>30 \%$ during the medium to high tidal ranges (Table 2.2).

For both field seasons the variables used in the regression models passed the tests for 
normality and independence among residuals $(P>0.05)$. The 1996 backward stepwise regression model fit the following equation $\left(R_{a d j}^{2}=0.45\right)$ :

Total $=-769.10+3480.48($ tide height $)+(-1.93)(\%$ cloud cover $\mathrm{X}$ temperature $)$.

The 1997 regression model fit the following equation $\left(R_{a d j}^{2}=0.66\right)$ :

Total $=-760.47+2386.51($ tide height $)+(-52.28)($ wind speed $)+5.55(\%$ cloud cover) +-106.71 (wind speed $X$ tide height).

Both models illustrate a strong positive relationship between tide height and total shorebirds counted on Lanark Reef. Of the variables measured, tide height alone accounted for $43 \%$ and $47 \%$ of the variance for 1996 and 1997, respectively.

\section{DISCUSSION}

The maximum number of shorebirds counted on the Reef increased by $>1000$ birds in 1997 compared to 1996 count data. Perhaps this was due to the wider tidal range in which the counts were conducted in 1997. Variability within shorebird counts remained similar; the coefficient of variation (CV) was 0.74 and 0.71 in 1996 and 1997, respectively. Intuitively, tide height affects available foraging space and prey availability. Species with different bill lengths feed on different prey species and will be affected by different tide heights (Evans 1979, Puttick 1984). Therefore, tide height will undoubtedly affect the number of shorebirds at feeding sites and will regulate when they leave feeding sites for roosting locations.

Previous studies accounted for 48 - $75 \%$ of the variance in shorebird numbers using tide height alone (Colwell 1993). Of the variables measured, I accounted for $43 \%$ and $47 \%$ of the variation using tide height alone in 1996 and 1997. While not affecting shorebirds as significantly, all variables were included in at least one of the models as either a single or interaction variable. However, deriving a biological explanation for these variables was difficult. Consequently, significant correlation coefficients were used to further describe these data.

Tide height was the only environmental variable I measured that was positively correlated with total count data from both 1996 and 1997. In addition, I looked at the environmental conditions within the high tidal ranges, for each year, which were at least two standard deviations below the regression line. In 1996 there was one such day; winds were 35 $\mathrm{km} / \mathrm{hr}$ during the count. In 1997 there were 4 low count days (i.e., two standard deviations below the regression line) during high tide. Each occurred with winds $\geq 15 \mathrm{~km} / \mathrm{hr}$, and on two of those days there was rain. Therefore inclement weather (high winds and/or rain) may explain why tide does not account for more variance. Based on the regression and correlation results, if maximum count of shorebirds using Lanark Reef is desired, I suggest counting at high tide (tide $>0.86 \mathrm{~m}$ at the Village Fina, but $<1.5 \mathrm{~m}$ due to possible complete inundation) and with wind $<$ $10 \mathrm{~km} / \mathrm{hr}$ and with zero precipitation.

In conclusion, I agree with Sprandel and Gore (1994) that the reef was used by shorebirds as a primary high tide roost. Of the total birds counted on Lanark in 1996 and 1997, 50\% were counted during high tide while roosting. However, I would suggest that the reef may also be an important feeding or low tide site for many shorebirds. On many occasions birds would fly to 
Lanark during a rising tide, purportedly from a feeding site, and continued feeding on Lanark before roosting. Additionally, $\geq 10 \%$ of the total count for shorebirds for each year were counted during low tide. Due to these observations, the significance of Lanark Reef as a feeding site should be further explored.

The reef was a primary high tide and common feeding site for many of the shorebirds in 1996 and 1997. Moreover, the reef supported 24\% of the Florida winter population for Marbled Godwits, American Oystercatchers, Snowy Plovers, Piping Plovers, and Willets in 1994

(Sprandel et al. 1997). It is relatively stable and experiences limited human disturbance. Due to the aforementioned reasons, I feel Lanark Reef is an optimal area for preservation and for the continued monitoring of these highly management-dependent migratory species. 


\section{LITERATURE CITED}

American Ornithological Union. 1998. American Ornithological Union checklist of North American birds, $7^{\text {th }}$ edition. A.O.U., Washington, D.C.

Colwell, M. A. 1993. Shorebird community patterns in a seasonally dynamic estuary. Condor 95:104-114.

Evans, P. R. 1979. Adaptations shown by foraging shorebirds to cyclical variations in the activity and availability of their intertidal invertebrate prey. Pages 357-366 in E. Naylor and R. G. Hartnoll, eds. Cyclic phenomenon in marine plants and animals. Pergamon Press, Elmsford, N.Y.

Jandel Scientific. 1994. SigmaStat statistical software. User's Manual. Jandel Scientific, San Rafael, CA. 825pp.

Millsap, B. A., J. Gore, D. E. Runde, and S. Cerulean. 1990. Setting priorities for the conservation of wildlife species in Florida. Wildl. Monogr. No. 111. 57pp. , and J. Feiertag. 1991. Coastal wildlife conservation plan. Florida Game and Fresh Water Fish Comm. Annu. Rep., Tallahassee. 18pp. + appendices.

Myers, J. P. 1983. Conservation of migrating shorebirds: staging areas, geographic bottlenecks, and regional movements. Amer. Birds. 37:23-25.

Puttick, G. M. 1984. Foraging and activity patterns of wintering shorebirds. Vol. 6. Pages 203-23 in J. Burger and B. L. Olla, eds. Shorebirds: migration and foraging behavior. Plenum Press, New York, N.Y.

Robertson, W. B. Jr., and G. E. Woolfenden. 1992. Florida bird species: annotated list special publication no. 6 of Florida Ornithological Society Gainesville. 260 pp.

Sasser, L. D., K. L. Monroe, and J. N. Schuster. 1994. Soil survey of Franklin County, Florida. U.S. Dep. Agric.

Sprandel, G. L., and J. Gore. 1994. Winter shorebird survey: annual report. Florida Game and Fresh Water Fish Comm., Tallahassee. 111pp. + appendices.

, J. A. Gore, and D. T. Cobb. 1997. Winter shorebird survey. Florida Game and Fresh Water Fish Comm. Final Perf. Rep. Tallahassee. 162 pp. + vi.

Wolfe, S. H., J. A. Reidenauer, and D. B. Means. 1988. An ecological characterization of the Florida Panhandle. U.S. Fish and Wildl. Serv. Biol. Rept. 88(12). 
Table 2.1 Counts and environmental conditions during the three minimum and maximum counts of total shorebird species on Lanark Reef, Franklin, Co., Florida for 1996 and 1997.

\begin{tabular}{|c|c|c|c|c|c|}
\hline Year & $\begin{array}{l}\text { Wind Speed } \\
(\mathrm{km} / \mathrm{hr})\end{array}$ & $\begin{array}{l}\text { Temperature } \\
\left({ }^{\circ} \mathrm{C}\right)\end{array}$ & $\begin{array}{l}\% \text { Cloud } \\
\text { Cover }\end{array}$ & $\begin{array}{l}\text { Tide } \\
\text { Height }(\mathrm{m})^{1}\end{array}$ & $\begin{array}{l}\text { Total } \\
\text { Count }\end{array}$ \\
\hline \multirow[t]{6}{*}{1996} & 9 & 20 & 0 & 0.53 & 55 \\
\hline & 4 & 13 & 37 & 0.70 & 73 \\
\hline & 14 & 12 & $---^{2}$ & 0.71 & 98 \\
\hline & 5 & 17 & 81 & 0.83 & 1598 \\
\hline & 25 & 19 & 5 & 1.00 & 1611 \\
\hline & 10 & 9 & 75 & 0.75 & 1917 \\
\hline \multirow[t]{6}{*}{1997} & 0 & 9 & 74 & 0.32 & 71 \\
\hline & 17 & 11 & 100 & 0.46 & 90 \\
\hline & 4 & 18 & 42 & 0.71 & 276 \\
\hline & 11 & 21 & 62 & 1.28 & 2857 \\
\hline & 8 & 22 & 32 & 1.37 & 2948 \\
\hline & 8 & 19 & 100 & 1.20 & 2977 \\
\hline
\end{tabular}

${ }^{1}$ Counts were conducted within the following tidal ranges: $0.53 \mathrm{~m}-1.2 \mathrm{~m}$ in 1996 and $0.32 \mathrm{~m}-$ $1.5 \mathrm{~m}$ in 1997.

${ }^{2}$ Dashed line represents missing data. 
Table 2.2 The percent of the total count, delineated by the low, medium, and high tidal ranges, for each species on Lanark Reef, Franklin, Co., Florida for 1996 and 1997. ${ }^{1}$

Species

\begin{tabular}{lrrrrrr} 
& \multicolumn{2}{c}{ Low $^{2}$} & \multicolumn{2}{c}{ Medium $^{3}$} & \multicolumn{2}{c}{ High $^{4}$} \\
& 1996 & 1997 & 1996 & 1997 & 1996 & 1997 \\
\hline AMOY & 17 & 16 & 40 & 29 & 43 & 55 \\
MAGO & 11 & 9 & 51 & 34 & 38 & 57 \\
WILL & 20 & 8 & 40 & 36 & 39 & 56 \\
REKN & 8 & 16 & 35 & 40 & 58 & 44 \\
SBDO & 12 & 13 & 47 & 36 & 40 & 49 \\
DUNL & 8 & 9 & 39 & 39 & 53 & 51 \\
SAND & 37 & 39 & 44 & 36 & 37 & 39 \\
WESA & 6 & 8 & 17 & 37 & 77 & 55 \\
RUTU & 19 & 15 & 42 & 37 & 39 & 49 \\
BBPL & 14 & 13 & 38 & 35 & 47 & 51 \\
PLOVERS & 14 & 19 & 38 & 39 & 48 & 42 \\
\hline
\end{tabular}

${ }^{1}$ Abbreviations given in Appendix A.

${ }^{2}$ Low tides ranged from $0.53 \mathrm{~m}$ to $0.71 \mathrm{~m}$ in 1996 and $0.32 \mathrm{~m}$ to $0.78 \mathrm{~m}$ in 1997.

${ }^{3}$ Medium tides ranged from $0.73 \mathrm{~m}$ to $0.82 \mathrm{~m}$ in 1996 and $0.79 \mathrm{~m}$ to $1.18 \mathrm{~m}$ in 1997 .

${ }^{4}$ High tides ranged from $0.86 \mathrm{~m}$ to $1.2 \mathrm{~m}$ in 1996 and $1.19 \mathrm{~m}$ to $1.53 \mathrm{~m}$ in 1997.

5 Plovers included Piping, Semipalmated, Snowy, and Wilson's plovers. 
Table 2.3 Correlation coefficients for total count of all species on Lanark Reef, Franklin, Co., Florida for 1996 and 1997 and the environmental variables.

\begin{tabular}{|c|c|c|c|c|}
\hline $\begin{array}{c}\text { Total Count } \\
\text { Year }\end{array}$ & $\begin{array}{l}\text { Wind Speed } \\
(\mathrm{km} / \mathrm{hr})\end{array}$ & $\begin{array}{c}\text { Temperature } \\
\left({ }^{\circ} \mathrm{C}\right)\end{array}$ & $\begin{array}{l}\% \text { Cloud } \\
\text { Cover }\end{array}$ & $\begin{array}{l}\text { Tide } \\
\text { Height (m) }\end{array}$ \\
\hline 1996 & $\begin{array}{l}-0.027^{\mathrm{a}} \\
0.889^{\mathrm{b}}\end{array}$ & $\begin{array}{l}0.194 \\
0.304\end{array}$ & $\begin{array}{l}0.266 \\
0.171\end{array}$ & $\begin{array}{l}0.586 \\
0.001\end{array}$ \\
\hline 1997 & $\begin{array}{l}-0.168 \\
0.376\end{array}$ & $\begin{array}{l}0.402 \\
0.027\end{array}$ & $\begin{array}{l}0.124 \\
0.513\end{array}$ & $\begin{array}{c}0.669 \\
<0.001\end{array}$ \\
\hline
\end{tabular}

a -The top number for each variable represents the $r$-value or correlation coefficient.

${ }^{\mathrm{b}}$ - The bottom number for each variable represent the $P$-value which is considered significant if $P<0.05$. 


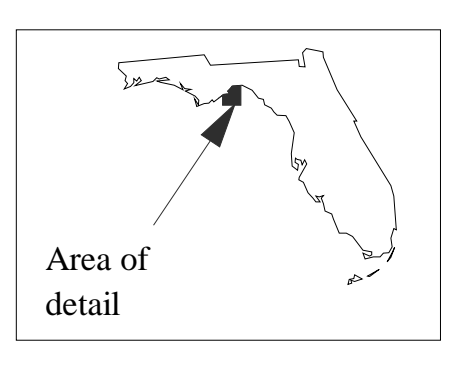

\section{WAKULLA COUNTY}

- Bald Point

\section{FRANKLIN COUNTY}

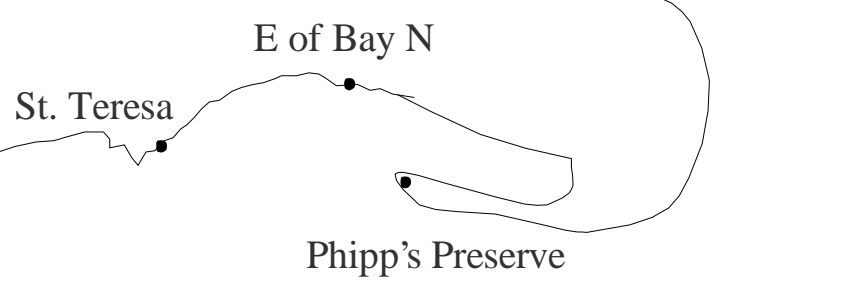

Sand Spit

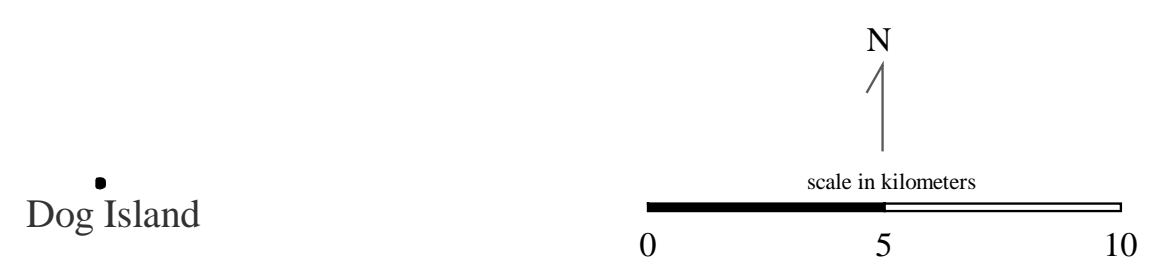

Figure 2.1 Lanark Reef Shorebird Complex, Franklin County, Florida 1995-97. 

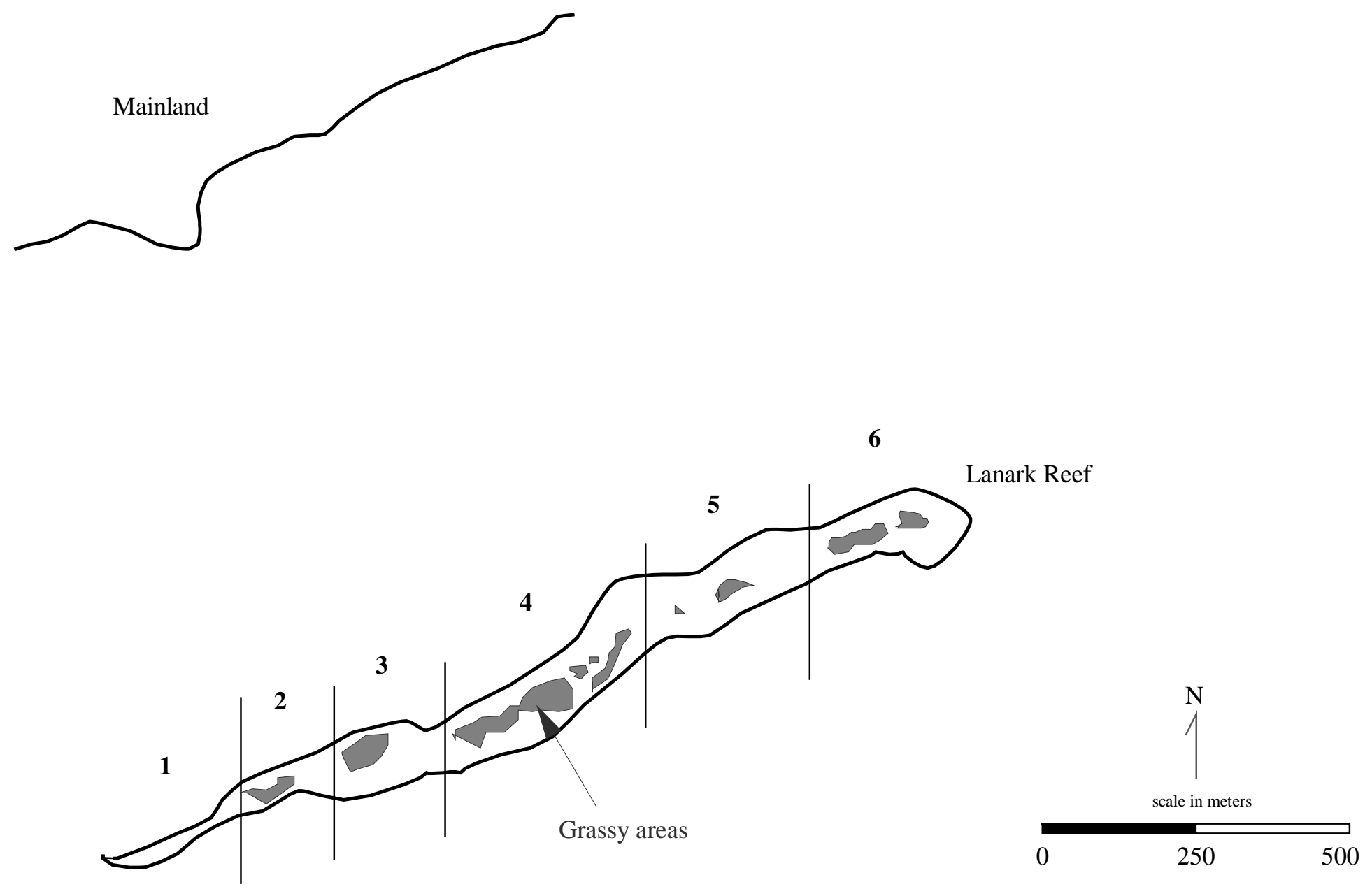

Figure 2.2 The location at low tide of quadrants on Lanark Reef, Franklin Co., Florida. 


\section{Average count 1996 \& 1997}

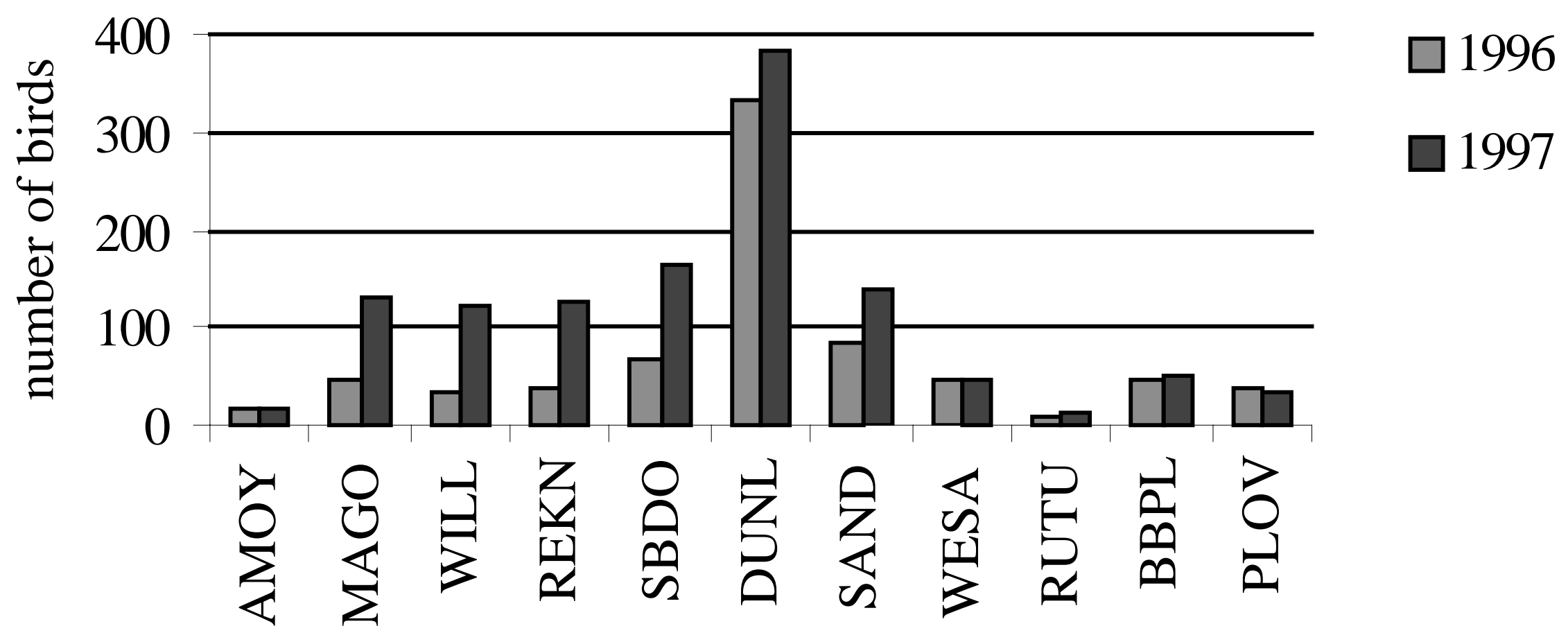

Figure 2.3 Average number of individual species counted on Lanark Reef, Franklin Co., January - March 1996 and January - February 1997.

(Appendix A lists species abbreviations) 
Appendix A. Shorebird species abbreviations

\begin{tabular}{lll}
\hline Common name & Scientific Name & Abbreviation \\
\hline Black-bellied Plover & Pluvialis squatarola & BBPL \\
Snowy Plover & Charadrius alexandrinus & SNPL \\
Wilson's Plover & Charadrius wilsonia & WIPL \\
Semipalmated Plover & Charadrius semipalmatus & SEPL \\
Piping Plover & Charadrius melodus & PIPL \\
American Oystercatcher & Haematopus ostralegus & AMOY \\
Willet & Catoptrophorus semipalmatus & WILL \\
Long-billed Curlew & Numenius americanus & LBCU \\
Marbled Godwit & Limosa fedoa & MAGO \\
Ruddy Turnstone & Arenaria interpres & RUTU \\
Redknot & Calidris canutus & REKN \\
Sanderling & Calidris alba & SAND \\
Western Sandpiper & Calidris mauri & WESA \\
Dunlin & Calidris alpina & DUNL \\
Short-billed Dowitcher & Limnodromus griseus & SBDO \\
\hline
\end{tabular}

${ }^{a}$ Piping, Semipalmated, Snowy, and Wilson's Plovers all included in group abbreviated PLOV. 